\title{
THE RIGHT TO RESTITUTION OF CULTURAL PROPERTY REMOVED AS SPOILS OF WAR DURING NINETEENTH- CENTURY INTERNATIONAL WARFARE
}

\author{
DR. YUE ZHANG*
}

\begin{abstract}
Many current disputes over cultural property resulted from war confiscations during nineteenth-century international warfare. India demands the return of the Kohinoor diamond from the United Kingdom, while China attempts to recover copper animal heads seized by the British and French armies. Do these states have legal rights under customary international law (CIL) to recover looted artifacts today when current conventions are not applied?

Scholars often argue that such claims have no basis in CIL. However, this article questions their conclusions because they retroactively apply the current CIL-making approach to determine whether any CIL rules existed in the nineteenth century. Instead, this article uses the intertemporal law approach to first identify the contemporaneous CIL-making criteria in the seventeenth through twentieth centuries, and then apply these tests to trace the evolution of the CIL rules against wartime looting of cultural property. I argue
\end{abstract}

\footnotetext{
* Associate professor, Southeast University, School of Law, China; S.J.D., University of Wisconsin-Madison Law School; Grant-Holder Visiting Fellow, Max Planck Institute for Comparative Public Law and International Law (yuezhangwisc@icloud.com). The draft of this article was presented at the Third World Approach to International Law Conference, Singapore, July 19, 2018; American Law and Society Annual Meeting, Toronto, Canada, June 10, 2018; Asian Law Institute (ASLI) Conference, Singapore, June 12, 2019. The author would like to especially thank her S.J.D. advisor Prof. Heinz Klug and her S.J.D. second reader Prof. Alexandra Huneeus for their advice. The author would like to thank Prof. James Gathii, Prof. CAI Congyan, Dr. Sebastian Spitra, Joseph Diedrich (J.D.), and Eric Klemm (J.D.) for reviewing and editing the article. The author also would like to thank Prof. Benedict Kingsbury, Prof. Antony Anghie, Raphael Schäfer, Yueyao Zhang, and Alexander Herman for comments and questions.
} 
that CIL has prohibited such practices and provided restitution as the primary remedy in circumstances of violations since the nineteenth century. This right to restitution has been established as a general rule that should be applied to all states rather than only Western "civilized nations." Moreover, the passage of over 150 years since the time of removal will not inhibit claims for restitution, so long as the plundered artifacts still exist and are identifiable. This article provides an original interpretation of CIL-making in the law of war with respect to cultural property and paves the legal grounds for claiming historically looted cultural property today. 


\section{TABLE OF CONTENTS}

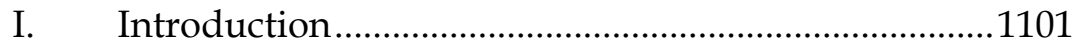

II. Restitution in General International Law .....................1109

a. The Jurisprudence of Restitution Under Current

International Law

b. Tracing the Jurisprudence of Restitution in the History of International Law.

III. The Evolution of the CIL Rule Against Wartime Plunder of Cultural Property 1113

a. The Formation of the CIL Rule Against Plunder in the Seventeenth and Eighteenth Centuries

i. $\quad$ The Approach to Identify the Formation of CIL Rules

ii. $\quad$ The Established CIL Rule Against Plunder ...1116

b. The Development of the CIL Rule Against Plunder in the Nineteenth Century.

i. $\quad$ The Approach to Identify the Validity of CIL

Rules as Previously Established.

ii. $\quad$ The CIL Rule Against Plunder Remained Valid

1. Napoleon's Looting and the Development of the CIL Rule Against Plunder...... 1121

2. Codification of the Established CIL Rule

Against Plunder

c. The Development of the CIL Rule Against Plunder in the

Twentieth Century 1125

IV. Restitution: Remedy for the Breach of the CIL Rule Against Plunder

a. Restitution After Napoleon's Defeat ........................1127

i. Dilemma on Restitution .................................1127

ii. $\quad$ The Legal Grounds for Claiming Restitution.1128

iii. Reaction of the Allied Powers to Restitution..1129

iv. Reaction of France to Restitution ...................1130

v. The CIL Right to Restitution...........................1132

b. The Development of the CIL Right to Restitution During and After World War I ...........................................1133

c. The Development of the CIL Right to Restitution During and After World War II........................................... 1134

i. $\quad$ Broad Definition of War Plunders .................1134

ii. $\quad$ Widespread Participation in Restitution........1136 
V. A General or European CIL Right to Restitution? .....1139

a. The Evolution and Application of the Law of War....1140

b. The So-Called Standard of Civilized Nations and

Disputes over Spoils of War .....................................1142

i. $\quad$ The Concept of Civilized Nations Under Natural

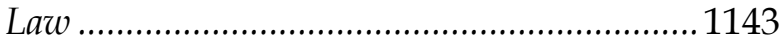

ii. $\quad$ The Changing Legal Significance of Civilized

Nations in the Nineteenth Century................ 1144

VI. The Passage of Time and the CIL Right to Restitution

1148

VII. Limitations to the Right to Restitution ........................1152

a. The Requirement that the Objects Still Exist and Are

Identifiable ............................................................... 1153

b. Necessity of Restitution ...........................................1153

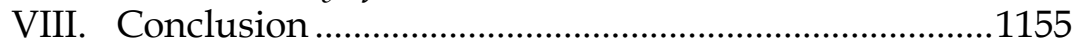




\section{INTRODUCTION}

This article discusses whether claiming states have legal rights in international law to the restitution of cultural properties 1 confiscated during international war in the nineteenth century. ${ }^{2}$ The nineteenth century witnessed an immense looting of cultural artifacts by Western powers from non-Western nations during their military confrontations. ${ }^{3}$ There are many current disputes over cultural property as a result from these armed conflicts. ${ }^{4}$ For

1 Claiming states refers to those states which claim to restitution of cultural properties plundered during nineteenth-century international warfare. The term "cultural property" refers to objects that are important to archeology, prehistory, history, literature, art, or science, on either religious or secular grounds. See Convention on the Means of Prohibiting and Preventing the Illicit Import, Export and Transfer of Ownership of Cultural Property art. 1, Nov. 14, 1970, T.I.A.S. No. 83-1202, 823 U.N.T.S. 231; Convention on Stolen or Illegally Exported Cultural Objects art. 2, June 24, 1995, 2421 U.N.T.S. 457; Council of Europe Convention on Offences Relating to Cultural Property art. 2(2), May 3, 2017, C.E.T.S. No. 221. For multiple ways of thinking about the concept of cultural property, see Francesco Francioni, Public and Private in the International Protection of Global Cultural Goods, 23 EUR. J. INT'L L. 719, 721-22 (2012).

2 This article adopts the term "restitution" as it discusses whether claims have the legal basis. For the differences between the terms of restitution, repatriation, and return, see UNESCO, Note on Terminology, in WITNESSES TO HISTORY, at xxiii (Lyndel V. Prott ed., 2009); CRAIG FORREST, INTERNATIONAL LAW AND THE Protection of Cultural Heritage 140-44 (2010); Wojciech Kowalski, Types of Claims for Recovery of Lost Cultural Property, in DisPlaCED CUltural AsSETS: THE CASE OF WESTERN EUROPE AND THE PROBLEMS OF CENTRAL AND EASTERN EUROPEAN Countries In THE Twentieth Century (Piotr Kosiewski \& Grazyna Czubek eds., 2004), reprinted in 57 MUSEUM INT'L, no. 4, 2005, at 85, 85-98.

3 For more information about how Western powers conducted vast plunder of cultural artifacts from other nations during this period, see generally Margaret M. Miles, War and Passion: Who Keeps the Art?, 49 CASE W. RsRV. J. INT'L L. 5, 14-17 (2017); Margaret M. Miles, Art as Plunder: The Ancient Origins of Debate About Cultural Property (Cambridge Univ. Press 2008); Wilhelm Treue, Art PLUNDER (Basil Creighton tran., 1961); WOJCIECH W. KOWALSKI, ART TREASURES AND WAR (Tim Schadla-Hall ed., 1998); Judith Grant, A Pillage OF ART (Roy Publishers, 1968); Russell Chamberlin, LoOt! The Heritage of Plunder (Facts on File 1983); IVAN LINDSAY, THE History OF LOOT AND STOLEN ART FROM ANTIQUITY UNTIL THE PRESENT DAY (Andrews UK Ltd. 2014) (2014) (ebook).

4 See, e.g., William R. Ognibene, Lost to the Ages: International Patrimony and the Problem Faced by Foreign States in Establishing Ownership of Looted Antiquities, 84 BROOK. L. ReV. 605, 605-33 (2019); Alice Lopes Fabris, South-South Cooperation on the Return of Cultural Property: The Case of South America, 49 CASE W. RSRV. J. INT'L L. 173, 173-96 (2017); Yoshiaki Sato, "Settled Completely and Finally": A Japanese Perspective on the Repatriationism of Cultural Property, 10 J.E. ASIA \& INT'L L. 197, $197-$ 219 (2017); Barbara Plankensteiner, The Benin Treasures: Difficult Legacy and Contested Heritage, in CUltural Property AND CONTESTED OWNERSHIP 133-55 (Brigitta 
example, British armies seized the Kohinoor diamond as a war trophy from India and presented it to the Queen of England in 1849.5 India has demanded the return of this diamond since its independence in 1947. ${ }^{6}$ This request was firmly refused by successive British prime ministers. ${ }^{7}$ As then Prime Minister David Cameron asserted, "If you say yes to one, you suddenly find the British Museum would be empty." 8 In another instance, British and French armies looted countless works of art from China's Old Summer Palace during the second Opium War in 1860.9 These artifacts were so unique that even French General Baron Montoubon who participated in this looting amazed, "[N]othing in our Europe can give an idea of equal luxury." 10 It is unclear where these plundered artifacts are currently located. ${ }^{11}$ Recently, art dealers have begun to frequently auction artifacts apparently belonging to China's Old Summer Palace. ${ }^{12}$ These auctions infuriated many

Hauser-Schäublin \& Lyndel V. Prott eds., 2017); Melissa (YoungJae) Koo, Note, Repatriation of Korean Cultural Property Looted by Japan - Can a Sincere Apology Resolve the Centuries-Old Korea/Japan Disputes?, 16 CARDOZO J. CONFLICT RESOL. 625, 625-50 (2015).

5 See Satish Jacob, Indian MPs demand Kohinoor's return, BBC NEws (Apr. 26, 2000, 17:11 GMT), http://news.bbc.co.uk/2/hi/south_asia/727231.stm [https://perma.cc/4RRM-5JUB]; Koh-i-Noor: India says it should not claim priceless diamond from UK, BBC NEWS (Apr. 19, 2016), http://www.bbc.com/news/worldasia-india-36079644 [https://perma.cc/TGT2-4XFU]; Ghoshray, infra note 292, at 749-50.

6 Ghoshray, infra note 292, at 752.

7 Koh-i-Noor, supra note 5.

$8 \quad I d$.

9 YounG-TSU Wong, A PARAdise Lost: THE IMPERIAL GARDEN YUANMING YUAN 139-143 (Univ. Hawai'i Press 2001); Bowlby, infra note 13.

10 WONG, supra note 9, at 139.

11 See Dong Lei (董否), Ying Paimaihang Qiangxing Paimai Cong Yuanmingyuan Jielue Wenwu Zhongguo Guojia Wenwuju Qianze (英拍卖行强行拍卖从圆明园劫掠文 物中国国家文物局谴责) [China's State Bureau of Cultural Property Condemned the British Auction House to Sell the China's Old Summer Palace Plunders], CANKAO XIAOXI ( 参 考 军 事 ) [MILITARY REFERENCE] (Apr. 11, 2018), http://www.cankaoxiaoxi.com/mil/20180411/2261289_2.shtml

[https://perma.cc/C3XH-A6PS] (noting that around 1.5 million items were originally plundered).

12 E.g., Bo Leung, Stolen relics spur strong feelings, CHINA DAILY (June 19, 2018, 15:19), https://www.chinadailyhk.com/articles/47/170/199/1529392506935.html [https://perma.cc/MC3H-F9TD]; 'Looted' Chinese treasures auctioned, BBC NEWS (May 2, 2000, 14:29 GMT), http://news.bbc.co.uk/2/hi/asia-pacific/733543.stm [https://perma.cc/3P5J-AXBB]. 
Chinese, which has spurred an ongoing state plan that the Chinese government attempts to recover these artifacts. ${ }^{13}$

These disputes are considered some of the most controversial issues today, which draw extensive discussions. Many authors argue for restitution under human rights law, emphasizing the importance of returning significant cultural artifacts to preserve the identity of peoples and communities. ${ }^{14}$ Other scholars in favor of restitution base their arguments on ethical or political grounds, such as redressing historical wrongs, ${ }^{15}$ consolidating national identities, ${ }^{16}$

2015),

3 Chris Bowlby, The palace of shame that makes China angry, BBC NEws (Feb. 2, [https://perma.cc/GAY7-F8FK] (quoting Niu Xianfeng, General Director of the National Treasures Fund, which is affiliated with the Chinese Ministry of Culture, "We're making a plan to start a series of actions to recover these antiques and get them back to China."); see also Leung, supra note 12

14 See, e.g., Evelien Campfens, The Bangwa Queen: Artifact or Heritage?, 26 INT'L J. Cultural PROP. 75-110 (2019) ("A human rights law approach to restitution claims can be understood as the acknowledgement of a right to possess, access, or control certain involuntary lost cultural objects on the grounds of their intangible heritage interests for specific people ...."); Francesco Francioni \& Lucas Lixinski, Opening the Toolbox of International Human Rights Law in the Safeguarding of Cultural Heritage, in HeRITAGE, Culture AND Rights 11, 18 (Andrea Durbach \& Lucas Lixinski eds., 2017) (arguing for a recognition of cultural heritage as a "full member" of the legal framework of human rights); Sarah Fründt, Return LogisticsRepatriation Business: Managing the Return of Ancestral Remains to New Zealand, in Cultural PROPERTY AND CONTESTED OWNERSHIP 178-97 (Brigitta Hauser-Schäublin \& Lyndel V. Prott eds., 2017) (describing New Zealand's repatriation program, its implementation and potential improvements). See generally CULTURAL HUMAN RigHTS (Francesco Francioni \& Martin Scheinin eds., Martinus Nijhoff Pub. 2008) (analyzing the concept of culture and human rights and to assess the impact that they are having on international law and the development of a coherent category of cultural human rights).

15 See, e.g., Elazar Barkan, Amending Historical Injustices: The Restitution of Cultural Property--An Overview, in Claiming THE STONES, NAMING THE BONES: CUltural Property AND THE NEgOtIATION OF NATIONAL AND ETHNIC IDENTITY 16-46 (Elazar Barkan \& Ronald Bush eds., 2002); ELAZAR BARKAN, THE GUILT OF NATIONS 308-51 (2000); PATRICK J. O'KeEFE \& Lyndel V. ProtT, 3 LAW AND the Cultural HERITAGE 839-43 (1984).

16 See O'KeEfe \& PROTT, supra note 15; Valdimar Tr. Hafstein \& Martin Skrydstrup, Heritage vs. Property, in THE Routledge COMPANION TO CUltural PROPERTY 38, 39 (2017) (regarding “[c]ultural property as a technology of sovereignty"); Charlotte Edwardes \& Catherine Milner, Egypt demands return of the Rosetta Stone, TELEGRAPH (Jul. 20, 2003), https://www.telegraph.co.uk/news/worldnews/africaandindianocean/egypt/1 436606/Egypt-demands-return-of-the-Rosetta-Stone.html

[https://perma.cc/V95J-HLFN] ("[T]hey should volunteer to return the Rosetta Stone because it is the icon of our Egyptian identity."). 
or carrying out the necessary steps of decolonization. ${ }^{17}$ Some scholars, however, reject these claims as having weak connections to the culture of modern states or having merely political or moral sentiment without a legal basis. ${ }^{18}$ Many scholars also analyze this issue in the context of debates about cultural property internationalism and cultural property nationalism, which address whether cultural property should be considered a common heritage belonging to all peoples or a national heritage only belonging to certain countries. ${ }^{19}$

This article focuses on the essential legal issue, which has been rarely discussed, as to whether claiming states have legal rights in the law of war to recover cultural property confiscated during nineteenth-century warfare. ${ }^{20}$ Although current conventions dealing with cultural property in the event of armed conflicts cannot be retroactively applied, ${ }^{21}$ this limitation does not necessarily impact

17 See A.F. Vrdoljak, International Law, Museums and the Return of Cultural Objects, in WITNESSES TO HISTORY, supra note 2, at 195; O'KEEFE \& PROTT, supra note 15.

18 See, e.g., O'KEEFE \& PROTT, supra note 15, at 839-41; John Henry Merryman, Thinking about the Elgin Marbles, 83 MiCH. L. REV. 1881, 1915-16 (1985); JAMES Cuno, Who Owns AnTiQuity? The Battle Over Our AnCiEnt Heritage 21-66 (Princeton Univ. Press 2008).

19 John H. Merryman initiated this debate. See Merryman, supra note 18, at 1901; John Henry Merryman, Two Ways of Thinking about Cultural Property, 80 AM. J. INT'L L. 831, 831-53 (1986); John Henry Merryman, Cultural Property Internationalism, 12 INT'L J. CULTURAL PROP., 11, 11-39 (2005); John Henry Merryman, The Nation and the Object, in Whose Culture? 183-203 (James Cuno ed., 2009). For recent discussions, see Sabrina Y. Hsieh, The Charitable Deduction and Looting of Antiquities: A Comparative Approach, 51 CORNELL INT'L L.J. 471, 474-75 (2018); Grant Strother, Resolving Cultural Property Disputes in the Shadow of the Law, 19 HARV. Negot. L. Rev. 335, 357-58 (2014); Raechel Anglin, The World Heritage List: Bridging the Cultural Property Nationalism-Internationalism Divide, 20 YALE J.L. \& HuMANS. 241, 241-75 (2008).

20 Different from this article, many scholars discuss the legal issue of cultural property in the context of the Nazis looting during the Holocaust era and World War II. See, e.g., Victoria Bonadies, Taking Greater Responsibility: Austria's Art Restitution Act and the Need for Further Reform, 34 AM. U. INT'L L. REV. 671, 671-99 (2019); Jennifer A. Kreder, Analysis of the Holocaust Expropriated Art Recovery Act of 2016, 20 Chap. L. ReV. 1, 1-25 (2017); KEVIN P. RAY, TRANSACTIONS IN ART \& CULTURAL PROPERTY 133-54 (2016).

21 See Convention for the Protection of Cultural Property in the Event of Armed Conflict art. 4, May 14, 1954, 249 U.N.T.S. 215 [hereinafter the 1954 Hague Convention]; The 1954 Hague Convention, supra, Protocol, art. 3, at 358; Protocol Additional to the Geneva Conventions of 12 August 1949, and Relating to the Protection of Victims of International Armed Conflicts (Protocol I) art. 53, June 8, 1977, 1125 U.N.T.S. 3; Second Protocol to the Hague Convention of 1954 for the Protection of Cultural Property in the Event of Armed Conflict art. 6, Mar. 26, 1999, 
whether there is any equivalent rule of customary international law (CIL) as discussed by this article. There have been increasing state practices across the world to return cultural artifacts plundered during warfare of previous centuries to their countries of origin. ${ }^{22}$ For example, the United States returned three church bells, which were seized by American soldiers as war trophies from the Philippines in 1901, to Philippine authorities in December 2018. ${ }^{23}$ These practices raise an important question as to whether they reflect a basis in CIL for restitution.

It is a well-established CIL rule that "[a] state responsible for an internationally wrongful act is under an obligation to make restitution." 24 In this regard, to establish restitution under the law of war, it is necessary to first inquire whether a CIL rule that prohibited wartime looting of cultural artifacts (the CIL rule against plunder) existed in the nineteenth century. Many scholars argue that the CIL rule against plunder has been established since the end of the nineteenth century, which was demonstrated by the adoption of the Hague Conventions of 1899 and 1907.25 These conventions remarkably showed a general consensus on the law of war, as states from different continents and political backgrounds sat together to discuss this matter for the first time ever. ${ }^{26}$ Alternatively, many other scholars claim that this rule was created due to increasing state

2253 U.N.T.S. 172; Convention with Respect to the Laws and Customs of War on Land art. 56, Jul. 29, 1899, T.S. No. 403 [hereinafter the 1899 Hague Conventions]; Convention Respecting the Laws and Customs of War on Land art. 56, Oct. 18, 1907, T.S. No. 539 [hereinafter the 1907 Hague Conventions].

22 See infra text accompanying notes 265-281.

23 Julie McCarthy, U.S. Returns Balangiga Church Bells To The Philippines After More Than A Century, NPR News (Dec. 11, 2018, 5:05 AM ET), http://www.npr.org/2018/12/11/675505073/after-117-years-balangiga-bellswill-be-returned-to-the-philippines [https://perma.cc/98VM-ZJ7D].

24 Infra note 42 , at art. 35.

25 Charles de Visscher argued that the doctrine of international law against plundering cultural property was accepted by all nations during the two Hague Conventions in 1899 and 1907. Charles de Visscher, International Protection of Works of Art and Historic Monuments, DOCUMENTS \& STATE PAPERS OF JULY 1949, reprinted in 8 INT'L INFO. \& CUlTURAL SERIES 821, 827-28 (1949). Merryman argued that international law prohibited plundering since the late nineteenth century. See JOHN Henry Merryman \& Albert E. Elsen, LaW, Ethics, AND the Visual ArTs 14 (2d ed. 1987). Wayne Sandholtz argues that this legal norm was transmitted into general international law at the end of the nineteenth century due to the adoption of the Hague Conventions of 1899 and 1907. See WAyne SANDHOLtZ, Prohibiting Plunder, How Norms Change 39-45, 67-70 (Oxford Univ. Press 2007).

26 Andrew Webster, Hague Conventions $(1899,1907)$, in THE ENCYCLOPEDIA OF WAR (Gordon Martel ed., 2012). 
practices to protect cultural artifacts in the context of the two World Wars. ${ }^{27}$ Moreover, widespread participation of states in returning looted cultural artifacts to their countries of origin occurred after the end of World War II. ${ }^{28}$ In light of this history, these scholars thus agree that the law of war in the nineteenth century did not forbid the looting of cultural artifacts. ${ }^{29}$

These scholars clearly make their arguments by applying the two-element approach to identify CIL, which requires general state practice and the opinio juris (or acceptance as law). ${ }^{30}$ General state practice must be "sufficiently widespread and representative, as well as consistent." 31 Opinio juris refers to a feeling or belief that states have legal rights or obligations to perform certain practices. ${ }^{32}$

27 Patrick J. O'Keefe, who has studied the return of dispossessed cultural property for more than forty years, observes that the principle against wartime looting was established in the early twentieth century. See PATRICK J. O'KeEFE, Protecting Cultural Objects: Before AND After 1970 3-4 (Inst. Art \& L. 2017) (outlining different treaties on wartime looting in the early twentieth century). Wojciech Kowalski, who has given contributions to addressing the international right to restitution as well as its principles, argues that this right was fully established after World War I. KOWALSKI, supra note 3, at 81. For more scholars who follow their ideas, see Duncan Chappell \& Saskia Hufnagel, The Gurlitt Case: German and International Responses to Ownership Rights in Looting Cases, in CULTURAL Property CRIME 221-22 (Joris D. Kila \& Marc Balcells eds., 2014); Karen Goepfert, The Decapitation of Rameses II, 13 B.U. Int'1 L.J. 503, 520-25 (1995).

28 See infra text accompanying notes 192-220.

29 See supra notes 25, 27 and accompanying text; MILES, ART AS PLUNDER, supra note 3 , at 349-53.

30 For the two-element approach, see Statute of the International Court of Justice, art. 38(1)(b), June 26, 1945, T.S. No. 993 [hereinafter the ICJ Statute]; Int'1 Law Comm'n, Draft Conclusions on Identification of Customary International Law with Commentaries, Conclusion 2, U.N. Doc. A/73/10, at 124 (2018) [hereinafter the ILC].

31 ILC, supra note 30, at 135; cf. North Sea Continental Shelf (Ger./Den. v. Ger./Neth.), Judgment, 1969 I.C.J. 3, $\$ 73$ (Feb. 20):

With respect to the other elements usually regarded as necessary before a conventional rule can be considered to have become a general rule of international law, . . . a very widespread and representative participation in the convention might suffice of itself, provided it included that of States whose interests were specially affected.

See also Military and Paramilitary Activities in and Against Nicaragua (Nicar. v. U.S.), Judgment, 1986 I.C.J. 14, ๆ186 (June 27) ("The Court does not consider that, for a rule to be established as customary, the corresponding practice must be in absolutely rigorous conformity with the rule.").

32 See, e.g., SS. Lotus (Fr. v. Turk.), Judgment, 1927 P.C.I.J. (ser. A) No. 10, at 28 (Sept. 7); North Sea Continental Shelf, supra note 31, at \$77; Jurisdictional Immunities of the State (Ger. v. It.: Greece Intervening), Judgment, 2012 I.C.J. 99, 122, ๆ55 (Feb. 3); Right of Passage over Indian Territory (Port. v. India), Judgment, 
However, this two-element test only represents our current understanding of how CIL is formulated and ascertained. ${ }^{33}$ Applying the current approach to examine the formation of CIL rules in earlier centuries is itself against the principle of nonretroactivity. Non-retroactivity is well recognized as the basic principle of law requiring the rules of law "not having effect from a date before it was made." 34 This principle requires an intertemporal law approach to examine the legality of CIL rules "by the legal standards valid at the time of its enactment." 35 In this respect, whether or not a nineteenth-century CIL rule existed should be determined by the contemporaneous nineteenth-century approach. However, it is unclear what the legal tests were to establish and develop CIL rules at that time. 36 This ambiguity makes the views of those scholars who claim that the law of war in the nineteenth century did not prohibit the looting of cultural artifacts questionable. ${ }^{37}$

This article uses the intertemporal law approach to first explore the CIL-making criteria of the seventeenth through twentieth centuries and then apply these tests to trace the evolution of the CIL rule against plunder and the CIL right to restitution as the legal

1960 I.C.J. 6, 9 (Apr. 12) (dissenting opinion by Chagla, J.); ILC, supra note 30, Conclusion 9 and Commentary (2), at 138.

33 This current approach can only be traced to Article 38 of the Statute of Permanent Court of International Justice of 1920. Statute of the Permanent Court of International Justice art. 38, Dec. 16, 1920, 6 L.N.T.S. 389.

34 Non-retroactivity, TRANSLEGAL, https://www.translegal.com/legal-englishdictionary/non-retroactivity [https://perma.cc/UHD2-NMDS].

35 Markus Kotzur, Intertemporal Law, in MAX PLANCK ENCYCLOPEDIAS OF INTERNATIONAL LAW para. 5 (Rüdiger Wolfrum ed, 2008), MPEPIL 1322, https://opil.ouplaw.com [https://perma.cc/Z6E8-29JY] (last visited Mar. 10, 2020).

36 The contemporary literature contains almost no analysis about legal tests prior to the current approach. However, there are other understandings of the formation of CIL rules in history than the intertemporal law approach. See, e.g., B. S. Chimni, Customary International Law: A Third World Perspective, 112 AM. J. INT'L L. 1, 1-46 (2018); J. Patrick Kelly, Customary International Law in Historical Context, in REEXAMINING CUSTOMARY INTERNATIONAL LAW 47, 47-85 (Brian D. Lepard ed., 2017).

37 Contrary to these scholars, Stanislaw E. Nahlik, a prominent contemporary international law jurist, stated that the plunder of cultural property was prohibited by the law of war in the nineteenth century, but he did not provide analysis to his argument. See Stanislaw E. Nahlik, International Law and the Protection of Cultural Property in Armed Conflicts, 27 HASTINGs L.J. 1069, 1071-72 (1976). 
remedy. ${ }^{38}$ These analyses reveal that "the rule against such plunder was indeed founded in the laws and customs of war in the eighteenth century, became well established in the nineteenth century, and further developed in the twentieth century." 39 On this basis, this article finds that the CIL right to restitution has been established as the primary remedy over compensation for violations of the CIL rule against plunder since the nineteenth century. It further argues that the right to restitution has been established as a general CIL rule that should be applied to all nations. Moreover, the passage of over one and a half centuries does not bar this right, so long as plundered artifacts still exist and are identifiable. States that were plundered in the nineteenth-century war therefore have strong legal grounds for claiming restitution.

This article is divided into eight parts beginning with the introduction. Part II analyzes the jurisprudence of restitution as a legal remedy in international law. Part III explores the legal tests for identifying CIL rules during the seventeenth through twentieth centuries and then applies these tests to examine the evolution of the CIL rule against plunder. Part IV investigates how restitution has

38 Although many scholars study the evolution of the rule that protects cultural property during armed conflicts, the question remains as to when and how this rule has been established in CIL. For examples of scholarship as such, see Rüdiger Wolfrum, Cultural Property, Protection in Armed Conflict, in Max PLANCK ENCYCLOPEDIAS OF INTERNATIONAL LAW (Rüdiger Wolfrum ed., 2010), MPEPIL 278, https://opil.ouplaw.com [https://perma.cc/Z6E8-29JY] (last visited Mar. 10, 2020); Patty Gerstenblith, Protecting Cultural Heritage in Armed Conflict: Looking Back, Looking Forward, 7 CARDOZO PUB. L. POL'Y \& ETHICS J. 677, 677-708 (2009); SANDHOLTZ, supra note 25; Sandholtz, infra notes 157 and 193; Patrick J. Boylan, The Concept of Cultural Protection in Times of Armed Conflict: From the Crusades to the New Millennium, in Illicit ANTIQUities: THE THEFT OF CUlTuRE AND THE EXTINCTION OF ARChAEOlogy 43-108 (Neil Brodie \& Kathryn Walker Tubb eds., 2003); Roger O'KeEFe, The Protection of Cultural Property in ARMed CONFlict 5-91 (2006); ForRest, supra note 2, at 63-73; JiRi TOMAN, THE ProteCtion of CULTURAL PROPERTY IN THE Event of ARMed Conflict 4-5 (Dartmouth Publ'g Co. 1996); StanislawEdward Nahlik, Protection of Cultural Property, in INTERNATIONAL DIMENSIONS OF HuMANITARIAN LAW 203-15 (UNESCO 1986); M. Cherif Bassiouni, Reflections on Criminal Jurisdiction in International Protection of Cultural Property, 10 SYRACUSE J. INT'L L. \& COM. 281, 287-97 (1983); O'KEEFE \& PROTT, supra note 15; de Visscher, supra note 25; Alan Marchisotto, The Protection of Art in Transnational Law, 7 VAND. J. Transnat'L L. 689, 689-724 (1973); Lakshmikanth Penna, Protection of Cultural Property During Armed Conflict, in SHELTER FROM THE STORM: DeVELOPMENTS IN INTERNATIONAL HuMANITARIAN LAW (Maley William ed. 1997); Andrea Cunning, The Safeguarding of Cultural Property in Times of War $\mathcal{E}$ Peace, 11 TULSA J. COMP. \& INT'L L. 211, 211-23 (2003); Joshua E. Kastenberg, The Legal Regime for Protecting Cultural Property During Armed Conflict, 42 A.F.L. REV. 277, 280-89 (1997).

39 Yue Zhang, Customary International Law and the Rule Against Taking Cultural Property as Spoils of War, 17 CHINESE J. INT'L L. 943, 943 (2018). 
been established as the primary remedy for the breach of the CIL rule against plunder. Part $\mathrm{V}$ discusses whether the CIL right to restitution has been a general CIL rule that should be applied to all nations since the nineteenth century. Part VI focuses on whether the passage of time inhibits the claims of restitution. Part VII inquires as to the limitations to enforcing restitution, which requires that the objects for restitution still exist and are identifiable, with a practical consideration of necessity that should be determined by claiming states. This article concludes by bringing together the results of my analysis in Part VIII. This article provides an original interpretation of CIL-making in history and the law of war in the protection of cultural property. Applying these conclusions to current disputes would thus ultimately transform the current debates about restitution and retention of displaced cultural property.

\section{RESTITUTION IN GENERAL INTERNATIONAL LAW}

This Part analyzes the jurisprudence of restitution as a state responsibility in current international law. It then traces the historical development of restitution to examine whether restitution was also established as the primary remedy for states' international wrongful acts starting in the seventeenth century, a period deemed to be the beginning of the modern international law era.

\section{a. The Jurisprudence of Restitution Under Current International Law}

According to Black's Law Dictionary, one of primary meanings of restitution refers to "return or restoration of some specific thing to its rightful owner or status." 40 Under international law, restitution defines a state's responsibility of reparation that arises from wrongful acts that states have committed. ${ }^{41}$ The International Law Commission (ILC)'s Articles on State Responsibility represent a great achievement by the Commission that codifies the law of state

40 Restitution, BLACK'S LAW DictionARY (11th ed. 2019), Westlaw.

41 JAMES CRAWFORD, THE INTERNATIONAL LAW COMMISSION'S ARTICLES ON StATE RESPONSIBILITY 213 (2002); see ILC U.N. Doc. A/56/10, infra note 42. 
responsibility. ${ }^{42}$ According to Article 35, restitution means "to reestablish the situation which existed before the wrongful act was committed." 43 Article 36(1) confirms that restitution serves as the primary remedy of reparation while state responsibility for compensation would be made only if "such damage is not made good by restitution." 44 The obligation to perform restitution could be precluded if the objects that would be subject to restitution are materially impossible to return. ${ }^{45}$ As the ILC's commentary to Article 35 explains, restitution serves as the first form of reparation because "restitution most closely conforms to the general principle that the responsible State is bound to wipe out the legal and material consequences of its wrongful act by re-establishing the situation that would exist if that act had not been committed." 46

The reasoning behind requiring restitution over compensation as the primary remedy of reparation is based on the Factory at Chorzów case of 1928. ${ }^{47}$ In this case, the Permanent Court of International Justice first provided a general definition of reparation:

The essential principle contained in the actual notion of an illegal act ... is that reparation must, as far as possible, wipe out all the consequences of the illegal act and reestablish the situation which would, in all probability, have existed if that act had not been committed. 48

The court then concluded that it was a basic rule of international law that states were liable for restitution due to violations of international law, and compensation should be made only if restitution was not possible. ${ }^{49}$

42 Int'l Law Comm'n, Rep. on the Work of its Fifty-Third Session, U.N. Doc. A/56/10 (2001), reprinted in [2001] 2 Y.B. INT'L L. COMM'N 96-97, U.N. DOC A/CN.4/SER.A/2001/Add.1.

43 Id. at art. 35.

44 See id. at art. 36(1) (establishing that the State should resort to restitution before compensating for the damage).

$45 \quad I d$. at art. 35(1).

46 Id. at art. 35; CRAWFORD, supra note 41.

47 Rep. on the Work of its Fifty-Third Session, supra note 42, at 91.

48 Factory at Chorzów (Ger. v. Pol.), Judgment, 1928 P.C.I.J. (ser. A) No. 17, at 47 (Sept. 13).

49 Id. 


\section{b. Tracing the Jurisprudence of Restitution in the History of International Law}

Many authorities refer to the Factory at Chorzów case when discussing the legitimacy of restitution in international law, 50 as if the legal rules for restitution were founded in general international law starting in this case. However, restitution was established as a legal remedy not only in Roman law, ${ }^{51}$ but also in the practices of warfare in ancient Roman era. As Pierino Belli, a classical international law writer observed, restitution had been one of main themes surrounding war and peace since the Ancient Greek and Roman eras. ${ }^{52}$ Hugo Grotius, who is often referred to as the founding father of international law beginning in the seventeenth century, listed many instances illustrating that Roman conquerors restored spoils of war to conquered parties when such looting violated the justice of war. ${ }^{53}$

Restitution was well established in the law of war during the seventeenth and eighteenth centuries. As Belli stated, "[P]eace restores everything to its original condition (so that what war has taken away is restored forthwith by peace)." 54 Restitution was prevalent especially when the capture of property was made contrary to just war or just cause. ${ }^{55}$ As Grotius wrote, "What [wa]s done in an unjust war [wa]s unjust in itself," and thus "what [wa]s

50 See CRAWFORD, supra note 41, at 213; Attila Tanzi, Restitution, in MAX PlanCK ENCYCLOPEDIA OF PUblic INTERNATIONAL LAW para. 1 (Rüdiger Wolfrum ed., 2013), MPEPIL 1094, http:/ / opil.ouplaw.com [https://perma.cc/Z6E8-29JY] (last visited Mar. 10, 2020). See generally Christine Gray, The Choice Between Restitution and Compensation, 10 EUR. J. INT'L L. 413 (1999) (discussing reference to the Factory at Chorzow case by the International Court of Justice in various cases involving restitution).

51 Restitution, supra note 40.

52 See 2 Pierino Belli, A Treatise On Military Matters 8 (James Brown Scott ed., Herbert C. Nutting trans., 1936) (noting that restitution was a frequent cause of wars).

533 Hugo Grotius, The Rights of WAR And PeAce 1419 n.2, 1513-15 (Richard Tuck \& Knud Haakonssen eds., Liberty Fund, Inc. 2005) (recalling "Macrinus restored the Prisoners and Booty to the Parthians, because the Romans had broken the Treaty without Cause.").

542 BELLI, supra note 52, at 284.

551 Hugo Grotius, The Rights of War And Peace 396, n.15 (Richard Tuck \& Knud Haakonssen eds., Liberty Fund 2005) (according to Saint Austin, "the Restitution of what was taken away unjustly" was deemed a well-accepted cause to start a just war, which was also written in the Canon law.). 
taken away by an Enemy in an unjust War, [should] be restored." 56 As Samuel Pufendorf, another classical international law writer in the seventeenth century, argued, "Whoever himself takes by unjust violence and keeps another's property is bound to restore it." 57 Christian Wolff, who was another classical international law writer in the eighteenth century, likewise held, "[W]ho wages an unjust war is bound to restore property taken by force from another whose war is just." 58

Restitution was also prevalent in early common law precedents, especially when the object was irreplaceable due to its historical and cultural significance. In the Pusey v. Pusey case of 1684, England's High Court of Chancery issued the order to restore an ancient horn to the plaintiff who inherited the horn from his ancestors. 59 This case suggests that monetary compensation could not replace restitution when the objects in dispute had unique historical and cultural significance. Likewise in the Falcke $v$. Gray case of 1859, in which the High Court of Chancery was requested to order the specific performance of a contract to purchase two china jars, ${ }^{60}$ the court noted, compensation would not be a satisfactory remedy for nonperformance, because the articles for purchase were of "unusual beauty, rarity and distinction." 61 Although these cases were not related to states' claims, these decisions reflected the jurisprudence of restitution as the primary remedy over compensation, especially when cultural artifacts were the objects that were subject to restitution. This jurisprudence also explains why CIL has adopted restitution as the primary remedy for the violations of the rule of the law of war that prohibits the looting of cultural property, as discussed by the following sections.

563 GROTIUS, supra note 53, at 1416, 1512.

572 SAmuel Pufendorf, Elementorum Jurisprudentiae Universalis Libri DUO [TWO BOOKS ON THE ELEMENTS OF THE UNIVERSAL LAW] 266, at para. 314 (27) (James Brown Scott ed., William Abbott Oldfather trans., 1931).

582 Christian WolfF, Jus Gentium Methodo Scientifica Pertractatum [The LAW Of NATIONS AcCording TO THE ScIENTIFIC MeTHOD] 407 (James Brown Scott ed., Joseph H. Drake trans., 1934).

59 Pusey v. Pusey (1684) 23 Eng. Rep. 465, 465; 1 Vern. 272, 273.

60 See Falcke v. Gray (1859) 62 Eng. Rep. 250, 252-55; 4 Drewry. 651, 656-65 (noting that usually the court would issue specific performance because the object at issue was so rare). The court ultimately decided to not award specific performance for contractual reasons. Id. at 255; 4 Drewry. at 665.

61 Id. at 252; 4 Drewry. at 658. 


\section{The EVOlution OF THE CIL RULE AgAinst WARTIME PLUNDER OF CULTURAL PROPERTY}

This part first explores the different legal tests for identifying CIL rules during the seventeenth through twentieth centuries and then applies these tests to illustrate how the CIL rule against such plunder was indeed founded in the laws and customs of war in the eighteenth century, became well established in the nineteenth century, and was further developed in the twentieth century.

\section{a. The Formation of the CIL Rule Against Plunder in the Seventeenth and Eighteenth Centuries}

Plundering an enemy's property had long been justified by the motto "to the victor belong the spoils" in early history. ${ }^{62}$ However, no one can deny that such practices are absolutely prohibited by international law today. ${ }^{63}$ Thus, it is clear that there has been a substantial change in the legal treatment of cultural artifacts during warfare over time. As this section shows, this shift indeed occurred during the seventeenth and eighteenth centuries under natural law jurisprudence.

\section{i. $\quad$ The Approach to Identify the Formation of CIL Rules}

The customary law of nations during the seventeenth and eighteenth centuries was not exactly identical to what we currently understand of CIL. ${ }^{64}$ The law of nations, a common term for

62 Leonard D. Duboff \& Sally H. Caplan, The Deskbook of Art LaW 129 (1977).

63 See generally supra notes 21 (describing current conventions dealing with cultural property in the event of armed conflicts), 38 (describing the scholarship on the evolution of the rule that protects cultural property during armed conflicts); $c f$. U.N. Secretary-General, Report of the Secretary-General Pursuant to Paragraph 2 of Security Council Resolution 808, U.N. Doc. S/25704, annex, Statute of the International Tribunal art. 3(d) (May 3, 1992) (subjecting prohibited seizures to prosecution).

64 The customary law of nations as a main source of international law was not as uniformly categorized as the CIL is today. Instead, different writers framed the customary law of nations in different categories. For instance, Grotius divided the 
international law at that time, was framed according to natural law philosophy, which deduced legal rules from the presumed supreme legal authority on the basis of law and morality. ${ }^{65}$ Under natural law, the law of nations adopted different sources of law than what we have today. ${ }^{66}$ First, the highest source of the law of nations was the writings of classical international law writers in their respective times. ${ }^{67}$ The significance for individual writers in identifying general international law is enormously different from today, as writings of international law publicists are now only considered as a "subsidiary means" to this end. ${ }^{6}$ Second, usage was considered the main body of the law of nations during this period. As the celebrated British Judge Lord Stowell observed in the Flad Oyen case of 1799, "A great part of the law of nations stands on [the usage and practice of nations]." 69 This proof value was influenced mostly by the British legal system, in which usages alone were able to create

law of nations into natural law and voluntary law, the latter category including the customary law of nations. 1 GROTIUS, supra note 55, at 147-60. de Vattel, on the other hand, classified the law into four categories - the necessary, the voluntary, the conventional, and the customary law of nations. EMER DE VATTEL, THE LAW OF NATIONS lviii §7, lxv-lxvi §27, (Joseph Chitty ed., Liberty 1844).

65 See T.J. LAWrence, Principles OF InTERnATIONAL LAW, 442-43 (Hans Kelson \& Robert Tucker eds., 2d ed. 1966); BIRGIT SCHLUTTER, DEVELOPMENTS IN CUSTOMARY INTERNATIONAL LAW 46 (Martinus Nijhoff Pub. 2010).

66 The international community has established a doctrinal system to ascertain the sources of international law since the beginning of the twentieth century, which categorizes the law as international conventional law, CIL, and general principles of law. See, e.g., Statute of the Permanent Court of International Justice, supra note 33 , art. 38 (1). The statute of ICJ accepted this doctrinal system of the sources with slight variations in expression. See, e.g., The ICJ Statute, supra note 30, art. 38 (1).

67 See Henry Sumner Maine, InTERnAtional LaW 14 (London, John Murray, 1888); GEORGE GRAFTON WiLSON \& GEORGE Fox TUCKER, INTERNATIONAL LAW 40-41 (5th ed. 1910) ("the writings of the great publicists . . . as the highest source of authority ... in the domain of international law"); ARCHER POLSON, PRINCIPLES OF THE LAW OF NATIONS 20-21 (Philadelphia, T. \& J. W. Johnson, 1853) (detailing the authority of text writers "whenever they record the usages and practice of nations").

68 The ICJ Statute, supra note 30, art. 38(1)(d).

69 The "Flad Oyen" (1799) 165 Eng. Rep. 124, 126; 1 C. Rob. 134, 139; see also HENRY WHEATON \& COLEMAN PHILLIPSON, WHEATON's ELEMENTS OF INTERNATIONAL LAW 5-6 (5th ed. 1916). Twiss also quoted this statement in his treatise of the law of nations in the nineteenth century. TRAVERS TWISS, TWO INTRODUCTORY LECTURES ON THE SCIENCE OF INTERNATIONAL LAW 52 (London, Longman, Brown, Green, and Longmans, 1856). 
legal rules..$^{70}$ The establishment of usages required uniform acts by nations with a long period of observation. ${ }^{71}$

Instead of a universal application, usages were usually valid only among nations that actually engaged in certain practices on a reciprocal basis. ${ }^{72}$ This feature explains why some customary rules were even optional and allowed states to unilaterally withdraw. ${ }^{73}$ However, mandatory customary rules did exist during the seventeenth and eighteenth centuries, and they had a universal application under natural law theory. Such mandatory customary rules required not only usages but also a subjective element, i.e., the law of nature, which was based on justice and reasonableness and could be proved by the use of reason. ${ }^{74}$ The law of nature indeed constituted the fundamental basis of natural law jurisprudence and made all rules of the law of nations legally binding. ${ }^{75}$ The validity of mandatory CIL rules thus had to be tested by the law of nature. ${ }^{76}$

Accordingly, the law of nations during the seventeenth and eighteenth centuries required two elements to identify mandatory CIL rules under natural law jurisprudence: usages on the basis of long-established and uniform practices, and the law of nature to validate those usages. This observation was well recognized in the Silesian Loan case of 1753 , as the British government defined the idea of "[t]he Law of Nations, founded upon Justice, Equity, Convenience and the Reason of the Thing, and confirmed by long

70 See Robert Morden, GeOgraphy Rectified: Or, A Description of the WORLD 22 (1688) ("The Common Law of England is a Collection of the General Common Custom, and Usages of the Kingdom."); see also Custom, OxFORD ENGLISH DICTIONARY (3d ed. 2015). Such importance is quite different from our understanding today that regards usage as merely the material element of CIL and requires state consent or opinio juris to be legally binding. See the ICJ Statute, supra note 30 , art. $38(1)(b)$.

71 As Suarez observed, usages among nations were binding in the intercourse among them, and such usages needed to be long observed and uniformly acted upon. TwISS, supra note 69, at 11.

72 DE VATTEL, supra note 64, at lxv $\$ 25$.

73 Cf. William S. Dodge, Withdrawing from Customary International Law: Some Lessons from History, 120 YALE L.J. ONLINE 169, 171-75 (2010), http:/ /yalelawjournal.org/forum/withdrawing-from-customary-internationallaw-some-lessons-from-history [https:// perma.cc/LU5N-7NLD].

74 See id.; 1 GrotiUs, supra note 55, at 147-60 (describing how different legal disciplines are tested by the law of nature).

75 SCHLÜTTER, supra note 65; PRINCIPLES OF INTERNATIONAL LAW, supra note 65.

76 See WM. OKe MANNING, COMMENTARIES ON THE LAW OF NATIONS 80 (London, S. Sweet 1839). 
Usage." 77 This statement was well recognized among European nations "as one of the ablest expositions of international law" at that time. ${ }^{78}$

\section{ii. The Established CIL Rule Against Plunder}

Looting an enemy's cultural artifacts had been a common practice since at least the Roman era, long justified by the traditional right of conquest. ${ }^{79}$ However, sovereigns in Europe began to stop plundering each other's cultural artifacts starting with the Peace of Westphalia of $1648 .{ }^{80}$ Moreover, the looting of cultural artifacts was abandoned almost entirely during the eighteenth century. 81 These uniform practices among European sovereigns, which continued for nearly one and a half centuries, strongly suggested that a new usage had been established to oblige parties engaging in warfare not to plunder cultural artifacts. ${ }^{82}$ It is interesting to question why this shift in practices of warfare occurred during the seventeenth and eighteenth centuries. It is not likely that the abstention from looting resulted from the lack of interest in looting or lack of capacity to

77 Arnold D. McNair et al., The Debt of International Law in Britain to the Civil Law and the Civilians, 39 PROBS. PUB. \& PRIV. INT'L L. 183, 192 (1953). This opinion was especially significant for demonstrating the relationship between usage and the law of nature. Id. at 194-95. The British Crown acquired this opinion from its officers including Lord Mansfield, who was deemed one of the most celebrated judges on the English bench. Id.; BRIERLY, infra note 99. Opinions as such were usually provided as confidential advice to the Crown. McNair et al., supra, at 19495. However, this opinion was written in reply to the Prussian statement of this case, and this made it publishable among other nations in Europe. Id.

781 Robert Phillimore, COMMENTARIES upON INTERNATIONAL LAW 55, para. XX (Philadelphia, T. \& J. W. Johnson 1854).

79 See de Visscher, supra note 25, at 823; MILES, ART AS PLUNDER, supra note 3, at 13, 52; MERRYMAN, supra note 25, at 13; Stephan Wilske, International Law and the Spoils of War: To the Victor the Right of Spoils? , 3 UCLA J. INT'L L. \& FOREIGN AFFS. 223, 242-43 (1998) (describing the Roman Empire's legal system regarding "spoils of artworks."); SANDHOLTZ, supra note 25, at 32-34.

80 See Penna, supra note 38, at 258; TREUE, supra note 3, at 162 (noting lack of large-scale art plundering in Germany and Austria since 1648); Merryman, infra note 173, at 325; de Visscher, supra note 25, at 824; Nahlik, supra note 38, at 203.

81 See de Visscher, supra note 25, at 824; PERCY BORDWELL, THE LAW OF WAR BETWEEN BELLIGERENTS 62 (1908) (describing the "respect shown for private property" by the British conduct during the War of 1812); cf. TREUE, supra note 3, at 162 (noting lack of big-scale plundering of art in Germany and Austria since the sack of Prague).

82 Zhang, supra note 39, at para. 32 (noting the abandonment from looting "starting with the Peace of Westphalia in 1648"). 
loot. ${ }^{83}$ Indeed, this new usage resulted from a change in the perception of justice and reasonableness that restricted the traditional right of conquest. ${ }^{84}$

During the seventeenth and eighteenth centuries, many classical international law writers sought to limit the damages of war and thus placed more restrictions on the right of conquest. 85 According to these jurists, it was just war and just cause that determined the treatment of an enemy's property. ${ }^{86}$ These jurists further related just cause to military necessity in the determination of what type of property could be seized. 87 Sacred objects and works of art especially were considered exceptions to the rules regarding the spoils of war. As Grotius emphasized, it was not necessary to use force upon artifacts that posed no danger to an army in a war but actually honored human society, such as temples and sacred objects. ${ }^{88}$ de Vattel further articulated that objects that did not increase the enemy's strength but honored human society should be excluded from spoils of war, including temples, tombs, public buildings, and all remarkable works of art. ${ }^{89}$

Grotius' and de Vattel's reasoning about the treatment of cultural artifacts during warfare reflected an updated understanding of the law of nature regarding the right of conquest. These writers' opinions were rooted in the development of civil society, which increasingly appreciated special values of cultural artifacts during the seventeenth and eighteenth centuries. As early as $70 \mathrm{BCE}$, the influential Roman jurist Marcus T. Cicero developed a philosophy about the fate of works of art when he prosecuted Governor Verres, who abused his authority by plundering artistic

$83 \quad$ Id. at 33.

84 Id.

85 See SANDHOLTZ, supra note 25, at 35-44 (illustrating the rise of art's status during the Renaissance and how writers sough to protect art from harms of wars).

86 Hugo Grotius, COMMENTARY ON THE LAW OF PRIZE AND BoOtY 89 (Martine Julia van Ittersum ed., Liberty Fund 2006); see 2 BELLI, supra note 52, at 131 (stating that "cities ought not to be plundered except for some great wrong and crime."); WOLFF, supra note 58 , at $402 \S 778$.

872 Alberico Gentili, De JuRe Belli Libri Tres [Three BoOKS ON THE LAW OF WAR] 270, 275 (Clarendon Press 1933); PUfENDORF, supra note 57, at 166, 245, 256; WoLFF, supra note 58, at 426-27 §§823-825 (discussing the "allowable destruction" in just wars).

882 Hugo Grotius, De Jure Belli ac Pacis Libri Tres [Three BoOKS ON THE LAW OF WAR AND PEACE] 751, para. V (Francis W. Kelsey trans., 1925) (articulating when "devastation should be refrained" during war).

89 DE VATTEL, supra note 64 , at $\$ 168$ (noting the justice and power of distributive justice). 
treasures. ${ }^{90}$ Cicero strongly emphasized the cultural value of works of art instead of merely focusing on their economic or religious value. ${ }^{91}$ Moreover, Cicero viewed these artifacts as absolutely essential to the life of a given people, arguing that cultural artifacts should be preserved in their original surroundings. ${ }^{92}$ Cicero's views did not draw much attention in his own time. However, in later centuries, the Renaissance enhanced the cultural impact of art in the development of humanism and thus ignited people's appreciation for cultural artifacts. ${ }^{93}$ Cicero's writings about the indisputable value of cultural artifacts to their territories of origin were then revived, serving as a vital precedent in debates about the ethical principles of collecting works of art. ${ }^{94}$ Cicero's arguments provided the philosophical basis not only for the emerging customary rule that prohibited plunder, but also required returning plundered artifacts to their territories of origin. ${ }^{95}$ Moreover, the ideologies of the Enlightenment promoted classical international law jurists to frame the law of nations by the use of reason. ${ }^{96}$ The looting of cultural artifacts could thus no longer be regarded as a natural right of conquest, because such practices were not considered a necessity for sovereigns to engage in or sustain a war. These changes all impacted the understandings of classical international law jurists about the law of nature regarding the right of conquest and especially the treatment of property.

The new usage that refrained from plundering each other's cultural artifacts, in conformity with the law of nature that restricted the right of conquest by military necessity, clearly manifested in the CIL rule that prohibited wartime looting of cultural property which was established at the end of the eighteenth century. Admittedly, this usage mostly appeared in Europe during this period. However, as Grotius emphasized, the law of nature was generally applied to all nations, because it represented "the common sense of

90 See Miles, Art As Plunder, supra note 3, at 2-3.

91 Id. at 363-64.

92 Cicero Comments on the Impact on Foreign Envoys to Rome of Verres' Plundered Art from Asia Minor, in MiLes, ART As Plunder, supra note 3, at 363-64; Cicero Comments on Scipio Aemilianus Repatriation of Art Booty from Carthage to Sicilian Cities, in MiLES, ART AS PLUNDER, supra note 3, at 366-67.

93 Nahlik, supra note 37, at 1071.

94 MiLES, ART AS PLUNDER, supra note 3, at 8.

95 Zhang, supra note 39, at para. 31.

96 See generally SANDHOLTZ, supra note 25, at 40-44 (describing the Enlightenment Era's impact on use of reason in international law). 
mankind." 97 The CIL rule against wartime plunder of cultural property based on the usage thus had a universal application because of the universal law of nature, even though the practices in conformity therewith were more common in Europe.

\section{$b$. The Development of the CIL Rule Against Plunder in the Nineteenth Century}

Although the CIL rule against plunder was established at the end of the eighteenth century, this rule might have been modified or abandoned due to the dynamic nature of CIL. This section thus explores two issues. It first inquires as to what was the legal test to identify the continuous validity of CIL rules that were previously established, especially when the law of nations shifted its philosophy away from natural law and toward positivism. It then applies this test to analyze whether the CIL rule against plunder was still valid during the nineteenth century.

\section{i. $\quad$ The Approach to Identify the Validity of CIL Rules as Previously Established}

The history of the nineteenth century witnessed the fundamental shift within the philosophy of international law from natural law toward positivism. This shift was not a sudden change but occurred gradually during that century. The question then arises as to how to evaluate the validity of CIL rules during the transitional period when natural law was being replaced with positivism. During this transitional period, the law of nature and state consent closely interacted with each other and mutually constituted the basis of CIL. State consent played an increasing role in identifying CIL at that time, which was primarily presumed to exist based on consistent state practices. 98 However, the law of nature should not be neglected. Many influential jurists in the nineteenth century still

97 Grotius, supra note 88, at 42.

98 See, e.g., N. Atl. Coast Fisheries (U.K. v. U.S.), 11 R.I.A.A. 167, 206 (Perm. Ct. Arb. 1910) (Draco, J., dissenting); The Paquete Habana, 175 U.S. 677, 700 (1900); Regina v. Keyn (The Franconia), 2 Exch. Div. 63, 202 (Lord Cockburn C.J. 1876) ("To be binding, the law must have received the assent of the nations who are to be bound by it."); David Kennedy, International Law and the Nineteenth Century: History of an Illusion, 65 NORDIC J. INT'L L. 385, 398 (1996). 
regarded the law of nature as the essential basis that determined the binding force of CIL. ${ }^{99}$ Henry Maine in particular pointed out that "[t]he most useful and practical part of the Law of Nations is, no doubt, instituted or positive law, founded on usage, consent, and agreement. But it would be improper to separate this law entirely from natural jurisprudence." 100 Wheaton also defined international law from the perspective of both natural law and positivism. ${ }^{101}$ The law of nature especially served as an essential basis to develop state consent in codifying the laws and customs of war during the second half of the nineteenth century. Francis Lieber, who initiated this effort by drafting the Lieber Code for the U.S. government in 1863, observed that rules were created through "[u]sage, history, reason, and conscientiousness, a sincere love of truth, justice and civilization." 102 His work strongly encouraged states to codify the law of war and indeed provided the material basis for the Brussels Declaration of 1874, the Oxford Manuals of 1880, and the Hague Conventions of 1899 and 1907.103 As the preambles of the Hague Conventions of 1899 and 1907 revealed, justice and reason were two of the main foundations in drafting these agreements. ${ }^{104}$

Meanwhile, the opinions of states began to draw increasing attention to identifying CIL rules. ${ }^{105}$ These opinions of states may

99 JAMES BRIERLy, THE LAW OF NATIONS 69 (Oxford Univ. Press 7th ed. 2012) (ebook) (quoting Lord Mansfield, "the law of nations is founded on justice, equity, convenience, and the reason of the thing, and confirmed by long usage."). Henry Halleck and James Lorimer also contended that it was the law of nature that made custom, usage and practice legally binding. H. W. HALLECK, ElEMENTS OF INTERNATIONAL LAW AND LAWS OF WAR 32 (Philadelphia, J. B. Lippincott \& Co. 1878); 1 JAMES LORIMER, THE INSTITUTES OF THE LAW OF NATIONS 19, 27 (Edinburgh, William Blackwood \& Sons 1883).

100 Maine, supra note 67, at 32.

101 WHEATON \& PHILLIPSON, supra note 69, at 22.

102 Richard S. HARTIGAN, LIEBER's CODE AND THE LAW OF WAR 10 (1983).

103 Zhang, supra note 39, at paras. 56-72.

1041899 Hague Conventions, supra note 21; 1907 Hague Conventions, supra note 21 .

105 See, e.g., LEWIS R. HARLEY, Francis Lieber, His LifE AND POlitical PHILOSOPHY 153 (New York, Columbia Univ. Press 1899) (providing testimony that the Lieber Code was drafted on the grounds of "the legal consciousness of civilized peoples."); SCHLUTTER, supra note 65, at 16 (arguing from Austin's perspective that international law was a framework "which [is] imposed upon nations or sovereigns by opinions current amongst nations."); Th. Baty, The Institute of International Law on Pacific Blockade, 21 L. MAG. \& L. REV. 285 (1896) (arguing that the opinions of nations laid the foundation for international law and made the rules valid to nations); WHEATON \& PHILLIPSON, supra note 69, at 90 (concluding that the usage and opinion of nations generally recognized that the right of intervention or interference was an incontrovertible right of sovereignty). 
serve as convincing proof that how states understood the law of nature, or can be used as a basis to develop state consent. ${ }^{106}$ Although the three theories are in tension with one another in legal philosophy, the law of nature, state consent, and the opinions of state "all played a significant role in developing customary international law during this period, but with different degrees of significance." 107 Accordingly, to test the validity of established CIL rules in the nineteenth century one must depend on an overall evaluation of the law of nature, state consent, and the opinions of states in a dynamic context.

\section{ii. $\quad$ The CIL Rule Against Plunder Remained Valid}

The nineteenth century provides two episodes for the investigation of whether the CIL rule that prohibited wartime plunder of cultural artifact remained valid during this period.

\section{Napoleon's Looting and the Development of the CIL Rule Against Plunder}

In the first case study, Napoleon conducted a systematic and organized looting of cultural property in Europe for nearly two decades. ${ }^{108}$ Because Napoleon's looting deviated dramatically from the CIL rule against such practices, this substantial deviation could have cast doubt on the validity of this rule at that time.

However, the CIL rule that prohibited wartime plunder of cultural property was, instead of being weakened, strengthened as a result of Napoleon's looting. Napoleon attempted to conceal his organized confiscation of cultural artifacts during his campaign in Belgium in 1794, which suggested that Napoleon knew that the right of conquest during that time did not permit the systematic looting

106 Zhang, supra note 39, at para. 14.

107 Id.

108 For background on how Napoleon conducted an immense plunder of cultural artifacts in Europe, see generally CECIL GOULD, TROPHY OF CONQUEST, THE Musée Napoléon AND THE CReAtion of the LOUVRe (1965); Patricia Mainardi, Assuring the Empire of the Future: The 1798 Fête de la Liberté, 48 ART J. 155 (1989); Dorothy M. Quynn, The Art Confiscations of the Napoleonic Wars, 50 AM. HIST. REV. 437 (1945). 
of cultural artifacts anymore. ${ }^{109}$ Napoleon, nevertheless, sought to abandon this restriction by using force to revive the Roman practice of looting. However, Napoleon's looting provoked strong condemnations across Europe and even within France. ${ }^{110}$ These public reactions, for the first time, were so forceful as to raise serious doubts about the legality of such looting, which convincingly suggests that "modern civilization was no longer tolerant of such a practice." 111

More significantly, the CIL rule that prohibited Napoleon's looting was strengthened by the critical responses of European sovereigns to his looting as being contrary to "every principle of justice and the usages of modern warfare." 112 These responses represented their respective states' opinions, which clearly reflected their views of the law of nature that underlay the justice and usages of modern warfare. On this basis, European sovereigns consented to return plundered artifacts to their territories of origin after Napoleon's final defeat. ${ }^{113}$ These acts of restitution not only confirmed the existence of the international obligation that prohibited such plunder but also developed this CIL rule by recognizing restitution as the primary remedy for its violation. ${ }^{114}$

\section{Codification of the Established CIL Rule Against Plunder}

States attempted to codify the laws and customs of war during the second half of the nineteenth century. The rule against wartime plunder of cultural property, inter alia, was included in these efforts. It started with the Lieber Code, which required in Articles 34-36 and 38 that monuments of art, religious temples, churches, and libraries should be spared unless the standard of military necessity was met. ${ }^{115}$ Article 35 especially called for the protection of classical works of art and libraries, "even when they are contained in fortified

109 Zhang, supra note 39, at paras. 41-42.

110 Id. at paras. $43-46$.

111 Id.

$112 I d$. at paras. 47-50 (quoting Viscount Castlereagh from infra note 153).

113 See discussion infra Section IV.a.4.

114 See discussion infra Section IV.a.5.

115 Instructions for the Government of Armies of the United States in the Field General Order No. 100, art. 34-36, 38 (War Dep't Apr. 14, 1863), reprinted in 3 THE WAR OF THE REBELLION 148 (1902) [hereinafter the Lieber Code]. 
places whilst besieged or bombarded."116 Compared to the Lieber Code, the Brussels Declaration had a stricter rule, which stated in Articles 8 and 38 that military necessity was not considered an exception for confiscation of property belonging to churches and museums of fine art. ${ }^{117}$ Article 53 of the Oxford Manual offered the strictest rule, stating, "All destruction or wilful damage to institutions of this character, historic monuments, archives, Works of art, or science, is formally forbidden, save when urgently demanded by military necessity." 118 The Hague Conventions of 1899 and 1907 followed the stipulation of the Brussels Declaration in their Conventions. ${ }^{119}$ The two Conventions also stated that competent authorities should prosecute perpetrators who conducted illicit confiscation. ${ }^{120}$ This provision was copied from Article 8 of the Brussels Declaration, which required that all seizure of institutions of religion or art, historic monuments and works of art "should be made the subject of [legal proceedings] by the competent authorities." 121 Later, the Nuremberg tribunal relied on the provisions in the Hague Conventions of 1899 and 1907 to prosecute war criminals who illegally confiscated works of art during World War II. ${ }^{122}$

As many nineteenth-century jurists observed, international agreements at that time may merely formalize the established CIL rules. ${ }^{123}$ The Nuremberg tribunal also confirmed, "[I]n many cases treaties do no more than express and define for more accurate reference the principles of law already existing." 124 The Lieber Code was not merely a U.S. martial law but rather a reflection of the

\footnotetext{
116 Id. at art. 35.

117 Project of an International Declaration Concerning the Laws and Customs of War, adopted by the Conference of Brussels art. 8, 38, Aug. 27, 1874, reprinted in 1 AM. J. INT'L L. 96 (1907) [hereinafter the Brussels Declaration].

118 Institute De Droit International, Les Lois De La Guerre Sur Terre [The Laws of War in Land] art. 53, (Sept. 9, 1880) [hereinafter the Oxford Manual of 1880].

119 See The 1899 Hague Conventions, supra note 21, at art. 46, 56; The 1907 Hague Conventions, supra note 21, at art. 46, 56;

120 The 1899 Hague Conventions, supra note 21, at art. 56, ("All seizure of . . such institutions, to historical monuments, works of art or science, is prohibited, and should be made the subject of [legal] proceedings.").

121 The Brussels Declaration, supra note 117, at art. 8.

122 See infra text accompanying note 136.

123 WHEATON \& PHILLIPSON, supra note 69 , at 24; WILSON \& TUCKER, supra note 67, at 88-89; PHILLIMORE, supra note 78, at 86.

124 Judgment of the Nuremberg International Military Tribunal (Oct. 1, 1946), reprinted in 41 AM. J. INT'L L. 172, 219 (1947).
} 
established law of war; as Article 4 stipulated, "Martial Law is simply military authority exercised in accordance with the laws and usages of war." 125 Fedor F. Marten, who drafted the Brussels Declaration, described the conference as "in a sense the natural development of a thought, which has long been recognized as just." 126 As the preamble stated, the Oxford Manual sought to observe the law of war by "codifying the accepted ideas of our age so far as this has appeared allowable and practicable." 127 Most provisions in the Hague Conventions of 1899 and 1907 also merely restated international law rather than amending it, ${ }^{128}$ including the rule against the plunder of cultural property. As the records reveal, there was a clear consensus about the drafting of Article 56 without any debates throughout all the meetings of both conferences. ${ }^{129}$ The context of Article 56 was thus unanimously adopted in conformity with the wording of the Brussels Declaration with only minor changes in expression. ${ }^{130}$

As this history shows, while these international agreements were formalized through state consent, this consent reflected a common understanding of established CIL rules at the time. The states' opinions were based on their observance of the law of nature as one of the foundations for these rules. In particular, the CIL rule against plunder was not created at that time by state consent, but rather, it was already established on a natural law basis. States recognized the existence of this rule and then accepted it by expressing their consent. The CIL rule against plunder thus

125 The Lieber Code, supra note 115, at art. 4 (establishing that the Code is a reflection of existing law of war in its title "Code for the Government of Armies in the Field as Authorized by the Laws and Usages of War on Land") (emphasis added).

126 FEDOR F. MARTENS, LA PAIX ET LA GUERRE: LA CONFÉRENCE DE BRUXELLES 1874 [PeAce AND War: The Brussels Conference of 1874] 76 (1901) (quoting as translated by the author of this article).

127 The Oxford Manual of 1880, supra note 118, at preface.

128 See generally The 1899 Hague Conventions, supra note 21 (preamble); The 1907 Hague Conventions, supra note 21 (preamble); 1 THE PROCEEDINGS OF THE Hague PeAce Conferences (The Conference of 1899) 272 (James Brown Scott ed., 1920); The Hague CONVENTIONS AND DeClarations of 1899 AND 1907, at xi (James Brown Scott ed., 2d ed. 1915); Hague Conventions (1899, 1907), supra note 26; WHEATON \& PHILLIPSON, supra note 69, at 25.

129 See THE CONFERENCE OF 1899, supra note 128, at 77, 261, 442; 1 THE Proceedings of the Hague Peace Conferences: The Conference of 1907631 (James Brown Scott ed., 1920); 3 The Proceedings of the Hague PeAce CONFERENCES: THE CONFERENCE OF 1907 239, 1054 (James Brown Scott ed., 1920).

130 MARTENS, supra note 126 , at 546, 563-64. 
remained continuously valid even though the philosophy of international law changed. ${ }^{131}$

\section{c. The Development of the CIL Rule Against Plunder in the Twentieth Century}

Positivism was well established as the primary foundation of the philosophy of international law throughout the twentieth century. ${ }^{132}$ Under this philosophy, the conventional approach to identifying CIL rules requires general state practice and opinio juris. In this approach, it is broadly agreed that once a CIL rule has been established, unilateral withdrawal from the rule by any state is usually not allowed. 133 Subsequent practices which prove to be inconsistent with the established CIL rules are thus generally considered a breach of the rules, until these rules are ultimately modified or abandoned by subsequent inconsistent practices over a period of time. ${ }^{134}$

During the twentieth century, the two World Wars provided significant occasions for examining the validity of this CIL rule through the lens of practices that substantially diverged from the

131 Zhang, supra note 39, at paras. 69-73.

132 Kennedy, supra note 98, at 398.

133 International Law Association, Statement of Principles Applicable to the Formation of General Customary International Law, 69 ILA Report of Conference 27 (2000):

There is fairly widespread agreement that, even if there is a persistent objector rule in international law, it applies only when the customary rule is in the process of emerging. It does not, therefore, benefit States which came into existence only after the rule matured, or which became involved in the activity in question only at a later stage. Still less can it be invoked by those who existed at the time and were already engaged in the activity which is the subject of the rule, but failed to object at that stage. In other words, there is no "subsequent objector" rule.

134 See Military and Paramilitary Activities in and Against Nicaragua (Nicar. v. U.S.), supra note 31, at para. 186 ("In order to deduce the existence of customary rules, the Court deems it sufficient that ... instances of state conduct inconsistent with a given rule should generally have been treated as breaches of that rule, not as indications of the recognition of a new rule."); K. Wolfke, Some Persistent Controversies Regarding Customary International Law, 24 Neth. Y.B. INT'L L. 1, 7-8 (1993); Maurice H. Mendelson, The Formation of Customary InTERnATIONAL LAW 174-75 (1998) (stating "established customary rules are rarely simply abolished: they are normally replaced by other rules."); MARK E. VILLIGER, CUSTOMARY INTERNATIONAL LAW AND TREATIES 48 (1985) ("As long as the previous opinio has not been eroded, and the new opinio is not established, the diverging practice remains a form either of persistent or subsequent objection."). 
law. Instead of being eroded, this CIL rule was strengthened by states' efforts to safeguard cultural artifacts from being removed during warfare. ${ }^{135}$ Acts of restitution after the two World Wars also developed this CIL rule by confirming that restitution was the primary remedy for violations of the law. Moreover, the looting of cultural property has been recognized as a war crime since the Nuremberg trials. During the trial of Alfred Rosenberg, who was notoriously known as the head of Nazi Special Task Force "Einsatzstab Reichsleiter Rosenberg" dedicated to the plunder of cultural artifacts, the International Military Tribunal found Rosenberg guilty of "looting cultural property in occupied territories" on the basis of Article 56 of the Hague Conventions of 1899 and 1907, and viewed this article, inter alia, as deriving from CIL that was recognized by all civilized nations. ${ }^{136}$ During this period, states further developed this rule through consistent efforts to conclude a special convention devoted to the protection of cultural property in war, which finally brought the 1954 Hague Convention and its first protocol to convene. ${ }^{137}$

\section{RESTITUTION: REMEDY FOR THE BREACH OF THE CIL RULE AGAINST PLUNDER}

This part investigates how restitution has been established as the primary remedy for violations of the CIL rule that prohibits wartime plunder of cultural property. Because violations of CIL rules provide occasions for examining the proper remedy under CIL, this investigation pays close attention to the instances of looting that occurred during Napoleon's reign and the two World Wars. Given that the history regarding wars and peace negotiations was an essential source of the law of nations at that time, ${ }^{138}$ this part especially investigates the history of how states negotiated, consented to, and enforced restitution in these circumstances.

\footnotetext{
135 Zhang, supra note 39, at paras. 75-77.

136 Judgment of the Nuremberg International Military Tribunal, supra note 124, at 235, 237-38, 282.

137 Zhang, supra note 39, at paras. 81-85.

138 See WheATON \& PHILLIPSON, supra note 69, at 22-31 (listing the history of wars and peace negotiations as one of the six sources of international law).
} 


\section{a. Restitution After Napoleon's Defeat}

There is some skepticism as to whether the outcome in favor of restitution after Napoleon's final defeat simply reflects the traditional right of conquest. This section shows that these acts of restitution were not arbitrary conclusions made by victorious powers, but an expression of the existing CIL, which regarded restitution as the only appropriate remedy for the breach of the established CIL rule against wartime looting of cultural artifacts.

\section{i. Dilemma on Restitution}

After Napoleon was first defeated in April 1814, the allied powers expressed divergent attitudes toward how they should deal with Napoleon's plundered artifacts. ${ }^{139}$ A group of victim states supported restitution, while Britain was reluctant to push this claim forward, and Russia was opposed to it because Britain and Russia worried that restitution might harm the political stability of the newly restored French monarchy. ${ }^{140}$ The French government took advantage of the allied powers' disagreement and strongly opposed the restitution claims. ${ }^{141}$ As a result, the first Treaty of Paris, signed on May 30, 1814, was silent on the return of plundered artifacts. ${ }^{142}$

However, Napoleon's return and his final defeat at Waterloo gave rise to a complete change in these circumstances and broke the impasse regarding restitution among the allied powers. The allied powers then began to negotiate matters regarding restitution. ${ }^{143}$ Meanwhile, the French government continued to protest against such matters partly on the grounds that many plundered artifacts already belonged to France as a result of existing treaties. ${ }^{144}$ However, given their coercive nature, these treaties could not grant the ownership of looted artifacts to France, as it was an established principle of international law that coerced treaties were unable to

139 TREUE, supra note 3 , at $187-88$.

140 SANDHOLTZ, supra note 25, at 57-58; Quynn, supra note 108, at 459-60.

141 TREUE, supra note 3, at 187.

142 Letter from The Duke of Wellington to Viscount Castlereagh (Sept. 23, 1815), in 3 BRITISH AND Foreign STATE PAPERS 1815-1816, at 207, 209 (London, James Ridgway \& Sons, Picadilly 1838) (1815).

143 Id. at 207.

144 SANDHOLTZ, supra note 25 , at 53-55. 
transfer the valid titles of property. ${ }^{145}$ France also claimed that the right of conquest during the time of Napoleon's rule permitted France to retain the artifacts that were not formally transferred by treaties. ${ }^{146}$ This debate raises an essential question as to what the legal basis was for the allied powers to regain their lost artifacts. In other words, did the restitution actions after the final defeat of Napoleon reflect another vicious cycle of exercising victorious power?

\section{ii. $\quad$ The Legal Grounds for Claiming Restitution}

During Napoleon's rule, Napoleon's extensive looting provoked strong condemnation from outside and even within France. ${ }^{147}$ Among all critics, Quatremère de Quincy, a prominent French archaeologist at the time, argued that these artifacts should not be removed because their artistic and historical value could only be fully appreciated in their original surroundings. ${ }^{148}$ Quatremère also argued that traditional Roman right of conquest had been abandoned by the eighteenth-century law of war and should not be revived ${ }^{149}$ Quatremère later petitioned the French government to stop confiscating these artifacts, which intensified the public debate on the legality of Napoleon's confiscation. Forty-seven of the most distinguished French artists at the time signed the petition against Napoleon's looting, while another group of thirty-seven lessdistinguished artists soon after sent a counter-petition defending the French government's looting on the grounds of the traditional right of conquest. 150 Although Quatremère's arguments and the public debate did not stop Napoleon's looting, Quatremère's idea and its circulation in European civil society prepared the philosophical basis for the restitution of plundered cultural artifacts to their territories of origin after Napoleon was defeated.

After Napoleon was finally defeated and during the peace negotiations in Paris, the allied powers sought to "discover a mode

\footnotetext{
145 Marchisotto, supra note 38, at 694; SANDHOLTZ, supra note 25, at 61-62.

146 SANDHOLTZ, supra note 25, at 53-55.

147 Zhang, supra note 39, at paras. 43-46.

148 TREUE, supra note 3, at 178.

149 Mainardi, supra note 108, at 156.

150 Id.
} 
of doing justice" regarding Napoleon's looting. ${ }^{151}$ In this process, two British diplomats played a central role in developing a consensus about restitution. One figure was the Duke of Wellington, the commander who defeated Napoleon at Waterloo and the lead British diplomat in Paris. He supported the restitution of stolen artistic treasures to their countries of origin on the grounds that Napoleon's looting violated the law of war. ${ }^{152}$ The other figure was Lord Castlereagh, the British diplomat to the Congress of Vienna, an assembly in 1814-1815 to reorganize Europe after Napoleon was defeated. Agreeing with Wellington, Castlereagh argued for restitution because Napoleon's looting was "contrary to every principle of justice and the usages of modern warfare." 153

Wellington and Castlereagh's understandings of the modern law of warfare confirmed that the CIL rule against plunder was established in the laws and customs of war at that time. Moreover, their arguments reflected that the right to restitution was the primary remedy as a natural outcome flowing from the violation of this prohibitive rule. As Castlereagh asserted, restitution of plundered cultural artifacts to their territories of origin was the "only guide to justice." 154

\section{iii. Reaction of the Allied Powers to Restitution}

Wellington circulated his opinion at the Paris diplomatic conference and received general support among other allied powers. 155 The Prussian minister, Prince Hardenberg, soon stated his total agreement with the British diplomats' reasoning. 156 Austria, Spain, the Low Countries, the German states, the Italian states, and the Vatican all claimed that France had no right to retain

151 Letter from The Duke of Wellington to Viscount Castlereagh, supra note 142 , at 207.

152 Select Committee on Culture, Media AND Sport, Memorandum SubMitTed by the COMMITTEE ON THE PARTHENON, 2000, HC 371-III, q 9 7.3-.4 (UK); Christopher Hibbert, Wellington: A Personal History 199 (1997).

153 Letter from Viscount Castlereagh to the Plenipotentiaries of Austria, Prussia, and Russia (Sept. 1815), in 3 BRITISH AND ForEIGN STATE PAPERS 1815-1816, supra note 142 , at 203-04.

154 Id. at 207.

155 See Quynn, supra note 108, at 448 and 452-53 (quoting to publications in the London Courier on Oct. 3-4, 1815).

156 Wayne Sandholtz, Plunder, Restitution, and International Law, 17 INT'L J. Cultural Prop. 147, 151 (2010). 
these plundered artifacts. ${ }^{157}$ They then rejected the request of the French government, which sought to include a clause in the second Treaty of Paris in 1815 to retain all the previously plundered cultural artifacts. ${ }^{158}$ Wellington, on behalf of the allied powers, rejected another French request, which proposed to make restitution to only a few victim states, such as Prussia. ${ }^{159}$ As Wellington explained, he acted for all the allied powers and therefore was obliged to claim restitution for all of them. ${ }^{160}$ Castlereagh also claimed that the allied powers bore the duty of facilitating the restitution of plundered cultural artifacts to their territories of origin. ${ }^{161}$

The opinion held among the allied powers about their rights to restitution was also expressed by their tacit consent to the Dutch proposal to enforce restitution by the Netherlands' own actions. During the peace negotiations in Paris, the Dutch representative intended to take action regarding restitution, since no satisfactory answers had come from France. ${ }^{162}$ Through Wellington, the Dutch representative inquired of the ministers of the allied powers whether they would oppose such action. ${ }^{163}$ As Wellington revealed, the allied powers had no objection to the Dutch proposed action. ${ }^{164}$ The absence of objection signaled that the allied powers as a whole formed tacit consent to exercising the right to restitution of plundered cultural artifacts.

\section{iv. Reaction of France to Restitution}

The belief that France had no right to retain plundered cultural artifacts existed not only among the allied powers but was also expressed within France itself. Prince Talleyrand-Périgord, the French representative who argued for France to retain plundered artifacts during the peace negotiations, admitted in his memoirs, "[P]erhaps the monuments of art should never have entered the

157 Id.

158 Letter from the Duke of Wellington to Viscount Castlereagh, supra note 142, at 209-10.

159 Id.

160 Id.

161 Sandholtz, supra note 156.

162 Letter from The Duke of Wellington to Viscount Castlereagh, supra note 142 , at 208.

163 Id.

164 Id. at 208. 
domain of conquest."165 Even Napoleon himself knew that modern warfare no longer permitted the traditional practice of looting cultural artifacts. ${ }^{166}$

The actual belief of the French government regarding the illegality of Napoleon's looting explains why they opposed restitution during negotiations, but tacitly consented to restitution in practice. For instance, Wellington sought the opinion of Louis XVIII, the newly restored French king, concerning which means of restitution would be least offensive to him. ${ }^{167}$ Louis XVIII replied that he could give no order upon this matter and Wellington might act as he thought proper. ${ }^{168}$ In another instance, Talleyrand advised the director of French museums to let the Prussians start packing their statues and busts during Prussia's negotiations with the museums. 169 Later, when Prussia attempted to remove their dispossessed artifacts from the Louvre but met the resistance of eighty French national guardsmen, the minister of the French National Guard instructed his men to allow the Prussian army to load their properties. ${ }^{170}$

These episodes once again confirmed the general belief that France had no right to retain these artifacts removed as spoils of war. France thus fulfilled its obligation of restitution and almost all the victim states eventually regained their lost cultural artifacts. ${ }^{171}$ More significantly, the right to restitution was not only reflected in acts of restitution, but also confirmed in the second Treaty of Paris, signed on November 20, 1815, which obliged France to return the plundered artifacts to their former sovereigns. ${ }^{172}$ It is worth noting that this peace treaty came after the allied powers' acts of restitution were completed. If acts of restitution were made only after this peace treaty was concluded, there might be doubt as to whether restitution was enforced merely on the grounds of treaty clauses and

1652 Charles Maurice de TAlleyrand-PÉRIGORd, MÉMOIRES, 1807-1815, at 343 (Plon 1957), as quoted in Sandholtz, supra note 156, at 152.

166 Zhang, supra note 39, paras. 41-42.

167 Letter from The Duke of Wellington to Viscount Castlereagh, supra note 142 , at 207.

168 Id. at 208.

169 TREUE, supra note 3, at 191.

170 Id. at 191-92.

171 Sandholtz, supra note 156, at 150; TREUE, supra note 3, at 195.

172 Tim ChapMAn, The CONGRESS OF VIENNA: ORIGINS, PROCESSES, AND RESUlts 55 (1998); CHARLES G. ROBERTSON, ENGLAND UNDER THE HANOVERIANS 472 (1930); Henry M. StepHENS, ReVOlutionARy Europe, 1789-1815, at 354 (1907). 
not identified as a general international law obligation to reparation. However, in this episode, restitution clauses concluded in the second Treaty of Paris convincingly suggests that acts of restitution were made on the CIL basis, which was then confirmed by peace treaty clauses.

\section{v. The CIL Right to Restitution}

As analyzed before, determining whether previously established CIL rules maintained their validity in the nineteenth century requires an overall investigation of the law of nature, state consent, and the opinions of state. Wellington and Castlereagh's arguments were made according to a general understanding of the justice and practice of modern warfare, which reflected the law of nature that restricted the traditional right of conquest and prohibited wartime plunder of cultural artifacts. It was not a onesided belief representing the interests of only victorious powers or of victim states, but rather an opinion shared by the French government and neutral states that were not victims of Napoleon's looting, such as Great Britain. Based on this general belief, European nations, including France, agreed to make restitution. In this sense, the outcome of restitution not only reflected the first-tier international obligation for states not to plunder cultural artifacts at that time, but also contributed to confirming restitution as the primary remedy. The outcome in favor of restitution thus was not another reflection of victors' right similar to the traditional right of conquest but was deeply established in the CIL of warfare. Although it was impracticable to gain restitution without having victory in war, such victory only provided the necessary means to enforce restitution rather than constituting the legitimate basis of these acts.

The CIL obligation regarding restitution was also reflected in the Marquis de Somerueles case of $1812 .{ }^{173}$ In this case, Britain seized a ship carrying cultural artifacts owned by the U.S. Pennsylvania Academy of the Fine Arts as war prizes during its war with the

173 The Marquis de Somerueles: Vice-Admiralty Court of Halifax, Nova SCOTIA STEWART'S VICE ADMIRALTY REPORTS 482 (1813), reprinted in JOHN H. Merryman, Note on the Marquis de Somerueles, 2 InT'L J. Cultural Prop. 319 (1996). 
United States in 1812. ${ }^{174}$ Judge Croke issued restitution on the grounds that " $\mathrm{t}]$ he arts and sciences are admitted amongst all civilized nations, as forming an exception to the severe rights of warfare, and as entitled to favour and protection." 175 This case was determined by the British Vice-Admiralty Court of Halifax, and decisions of admiralty courts were considered to be one of the main proofs for the law of nations in the nineteenth century. ${ }^{176}$ This case thus serves as a significant precedent showing the established CIL rule against artifact plunder and CIL obligation to restitution at that time.

\section{b. The Development of the CIL Right to Restitution During and After World War I}

Restitution of plundered cultural artifacts to their countries of origin after World War I were settled through peace treaties. This process began with the Treaty of Versailles of 1919 in Articles 245247, which obliged Germany to return plundered cultural artifacts to France, Belgium and other states. ${ }^{177}$ In addition to the Treaty of Versailles, other peace treaties also contained clauses concerning the restitution of looted cultural artifacts. ${ }^{178}$ As such, restitution clauses were not an occasional provision that only applied to Germany, but they remained a feature of many peace treaties arising from World War I.

More significantly, treaty provisions provided that artifacts for restitution were not limited to plunders during World War I, but also included plunders during the previous wars of the eighteenth century. Article 245 of the Treaty of Versailles required restitution

174 Id. at $319,321$.

175 Id. at 322.

176 Travers Twiss, THE LAW OF NATIONS CONSIDERED AS INDEPENDENT LEGAL COMMUnities 132 (Oxford, The Clarendon Press 1875); WILSON \& TUCKER, supra note 67 , at 37 .

177 Treaty of Peace Between the Principal Allied and Associated Powers and Germany art. 245-47, June 28, 1919, 225 C.T.S. 188 [hereinafter the Treaty of Versailles].

178 See, e.g., Treaty with Hungary, Hung.-U.S., art. 177, Aug. 29, 1921, 8 U.S.T. 982 [hereinafter the Treaty of Trianon]; Treaty with Austria, Austria-U.S., art. 195, annex I-IV, Sept. 10, 1919, 5 U.S.T. 215 [hereinafter the Treaty of Saint Germain]; Treaty of Peace Between the Principal Allied and Turkey art. 422, Aug. 10, 1920, S. TREATY Doc. No. 7 (1921) [hereinafter the Treaty of Sevres]; Sandholtz, supra note 156, at 158 (citing to the 1921 Treaty of Riga). 
of cultural objects seized by the German authorities from France during the 1870-1871 war. 179 The Treaty of Trianon of 1921 in Article 177 obliged Hungary to return "all the records, documents and historical material possessed by public institutions .... which have been removed since January 1, 1868."180 The Treaty of Riga of 1921 in Article 11 obligated the Soviet Union and Ukraine to return to Poland a variety of cultural and historical objects, which had been seized under imperial Russian occupation since 1772 and the reign of Catherine the Great. ${ }^{181}$ The Treaty of Saint Germain of 1920 required the Austrian authorities to return a list of looted cultural objects to what was then the State of Czechoslovakia, including objects that were removed as early as 1718.182 The Treaty of Sèvres of 1921 demanded that Turkey restored all objects of religious, archaeological, historical, or artistic interest confiscated before August 1914 to the government of the territory from which they were taken. ${ }^{183}$ Although this treaty never entered into force, the lack of treaty obligation does not diminish the treaty's value in reflecting the established CIL obligation to restitution arising from violations of the CIL rule against plunder. These restitution clauses not only reaffirmed the existence of the laws and customs of war that prohibited the looting of cultural property from the eighteenth through nineteenth centuries, but also confirmed that restitution served as the primary remedy for violation of the international obligation against artifact plunder.

\section{c. The Development of the CIL Right to Restitution During and After World War II}

\section{i. $\quad$ Broad Definition of War Plunders}

The widespread looting of cultural property that occurred during World War II pushed the international community to strengthen the CIL rule against plunder to prevent future violations. The Allies' efforts to restore plundered artifacts started with the

\footnotetext{
179 The Treaty of Versailles, supra note 177, at art. 245.

180 The Treaty of Trianon, supra note 178, at art. 177.

181 Sandholtz, supra note 156, at 158.

182 The Treaty of Saint Germain, supra note 178, at art. 195.

183 The Treaty of Sèvres, supra note 178, art 422.
} 
London Declaration announced in 1943, which attempted to give a formal warning to all concerned regarding the treatment of looted property during the war. ${ }^{184}$ The London Declaration was the founding agreement for the restitution during and after WWII and defined wartime plunder in a broad sense, which included every form of transfer of property, even transactions that were apparently legal in form. ${ }^{185}$ Practices of searching for looted artifacts and returning them to their territories of origin all followed this agreement. ${ }^{186}$ The United States, Great Britain, and France, along with the Federal Republic of Germany, signed the Bonn Convention in 1952. ${ }^{187}$ This convention further clarified the scope of what constitutes plunder to include taking under duress, larceny, requisitioning, and other forms of dispossession. 188 More extensively, cultural artifacts acquired as gifts would also be subject to restoration if those artifacts were obtained by use of duress or an individual's official position. ${ }^{189}$ Cultural artifacts acquired by purchase were likewise required for restitution, unless they had been brought into a given country for sale. ${ }^{190}$ Such a broad conceptualization of plunder was later adopted by the 1954 Hague Convention in Article 4, which requires contracting parties to "prohibit, prevent and, if necessary, put a stop to any form of theft, pillage or misappropriation of, and any acts of vandalism directed against cultural property." 191

184 Inter-Allied Declaration Against Acts of Dispossession Committed in Territories Under Enemy Occupation or Control, Jan. 9, 1943, reprinted in 1 FOREIGN Relations of the United States: Diplomatic PAPERs, 1943, at 443-44 (1943) [hereinafter the London Declaration].

185 Id.

186 See, e.g., infra note 208; see also Final Act ch. VI, art. 1, in DEP'T OF STATE, PUB. No. 2187, Conf. SERIES 55, United NATIONS MONETARY AND FinANCIAL CONFERENCE FINAL ACT AND RELATED DOCUMENTS 23 (1944), http://fraser.stlouisfed.org/files/docs/historical/eccles/036_17_0004.pdf

[https://perma.cc/YX3W-4NDL] [hereinafter the Final Act of the United Nations Monetary and Financial Conference]; John B. Howard, The Paris Agreement on Reparation from Germany, in THE DISTRIBUTION OF REPARATION FROM GERMANY 19 (1946) (noting the Resolution on (a) and (g) of restitution policies).

187 Convention on the Settlement of the Matters Arising out of the War and the Occupation, May 26, 1952, 6 U.S.T. 4411, 332 U.N.T.S. 219 [hereinafter the Bonn Convention].

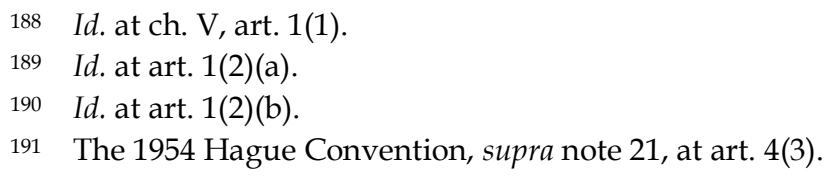




\section{ii. Widespread Participation in Restitution}

Placing the burden on military forces to protect cultural property during battles, particularly by establishing special institutions to send art professionals to the battlefield, became one feature of the law of war practiced during World War II. ${ }^{192}$ For example, the U.S. government set up the Roberts Commission and the Monuments, Fine Arts and Archives program (MFAA) in 1943 to carry out this mission. ${ }^{193}$ MFAA officers worked in the field to search out places where the German armies conceivably stored their looted artistic treasures and gathered information about the confiscation of artistic treasures by the Axis Powers. ${ }^{194}$ Similar special institutes were also established by the British government in the spring of $1944 .{ }^{195}$ These efforts not only strengthened the international obligation against plunder but also prepared for the restitution of looted artifacts after the war.

State practices of returning plundered artifacts after the war were widespread across the world. In Germany, restitution was first enacted through regulations and programs by the Allied Control Authority and military governments in different military zones until 1952. ${ }^{196}$ For example, Law 52 was adopted in September 1944, which banned transactions concerning all objects of cultural or historical value, irrespective of ownership. ${ }^{197}$ This regulation also required those who had custody of cultural property to carry out specific responsibilities, such as preserving and keeping records regarding those objects. ${ }^{198}$ Directive 1067, which was passed in July 1945 to further implement Law 52, instructed the military government in the U.S. zone of Germany (MGUS) to seize or block the transfer of "works of art or cultural material of value or importance, regardless of the ownership thereof." 199 The MGUS then set up a unilateral stopgap program in September 1945 for the return of stolen works

\footnotetext{
192 Zhang, supra note 39, at para. 77.

193 Wayne Sandholtz, Dynamics of International Norm Change: Rules Against Wartime Plunder, 14 EUR. J. INT'L RELS. 101, 116-17 (2008).

194 Id.

195 Id.

196 KOWALSKI, supra note 3, at 45-61.

197 Military Government of Germany, No. 9, Monthly Report of Military GOVERNOR U.S. ZONE 13 (1946).

198 Id.

199 KowALSKI, supra note 3, at 44.
} 
of art, among other plundered properties. 200 Meanwhile, uniform procedures were approved in 1945 for the restitution of cultural objects discovered in Germany that had been removed from formerly German-occupied countries. ${ }^{201}$ These programs, as well as the agreement on a definition of restitution, accelerated the process of restitution. ${ }^{202}$ Since 1952, the duty to continuously search for and return artifacts plundered during Germany's occupation of any territory was shifted from the Allied Control Authority and military governments to the Federal Republic of Germany through the Bonn Convention. ${ }^{203}$

In Austria, the Allied powers adopted similar restitution laws and regulations as they did in Germany. 204 After the Treaty on Reconstructing an Independent and Democratic Austria was concluded in 1955, the duty shifted to the Austrian government to restore all dispossessed artifacts that were presently in Austria. ${ }^{205}$

The restitution of looted artifacts discovered in Bulgaria, Hungary, Italy, and Romania was made through armistice and peace-treaty provisions. This process started with the Act of Surrender of Italy of 1943, which ordered the seizure of all property in Italy belonging to the Allied Nations, occupied countries, or their nationals. ${ }^{206}$ After that, armistice agreements with Hungary, Bulgaria, Finland, and Romania all included provisions to return artistic treasures that had been plundered by Axis powers and agencies during the Axis powers' occupation of these territories. ${ }^{207}$

\footnotetext{
200 Military GOVERnMENT OF GERMANY, No. 9, supra note 197, at 15.

201 Military Government of Germany, No. 6, Monthly Report of Military GOVERNOR U.S. ZONE 10 (1946).

202 Military Government of Germany, No. 9, supra note 197, at 15.

203 The Bonn Convention, supra note 187, at art. 1(1).

204 KowALSKI, supra note 3, at 46.

205 State Treaty for the Re-establishment of an Independent and Democratic Austria, May 15, 1955, 217 U.N.T.S. 225, art. 25(8)(d).

206 See KOWALSKI, supra note 3, at 61 (noting documents associated with the Act of Surrender of Italy 1943).

207 Agreement Between the Governments of the United States of America, the Soviet Union, and the United Kingdom on the One Hand and the Government of Romania on the Other Concerning an Armistice art. 12, Sep. 12, 1944, 59 Stat. 1712; Agreement Between the Governments of the United States of America, the Union of Soviet Socialist Republics and the United Kingdom, on the One Hand, and the Government of Bulgaria, on the Other Hand, Concerning an Armistice art. 11, Oct. 28, 1944, 58 Stat. 1498; Agreement Concerning an Armistice Between the Union of Soviet Socialist Republics, the United Kingdom of Great Britain and Northern Ireland, and the United States of America on One Hand and Hungary on the Other art. 1, Jan. 20, 1945, 59 Stat. 1321.
} 
These armistice provisions were later confirmed by peace treaties with Italy, Hungary, Bulgaria, Finland, and Romania. ${ }^{208}$ These peace treaty clauses clearly referred to the mutual understanding of plunder and restitution adopted by the London Declaration. ${ }^{209}$

In Japan, the Allied powers appointed the Far Eastern Commission to be in charge of the restitution of looted artifacts to the government of the countries from which these artifacts were removed. ${ }^{210}$ According to the U.S. Initial Post-Surrender Policy for Japan issued in 1945, "Full and prompt restitution will be required of all identifiable looted property." 211 The Far Eastern Commission summary report on January 4, 1946 further clarified looted property to include "objects of historical, cultural, and artistic value." 212 In particular, according to the Recovery of American Property Confiscated by Japanese in China report that was released to the press on October 16, 1947, "Looted property which was removed from China and is discovered in Japan is to be delivered by the Allied Military Authorities in Japan to the Chinese Government." 213

As for neutral states, any transfer of looted artifacts to or within these countries would be invalid according to the London Declaration. ${ }^{214}$ The final act of the United Nations Monetary and Financial Conference of 1944 followed this principle and required neutral states to take immediate measures to prevent any disposition or transfer of plundered property or concealment of property by fraudulent means within their territories. ${ }^{215}$ The United

208 Treaty of Peace with Italy art. 37, 75, Feb. 10, 1947, 61 Stat. 1245, 49 U.N.T.S. 3; Treaty of Peace with Hungary, art. 11, Feb. 10, 1947, 61 Stat. 2065, 41 U.N.T.S. 135; Treaty of Peace with Bulgaria, art. 22, Feb. 10, 1947, 61 Stat. 1915, 41 U.N.T.S. 21; Treaty of Peace with Finland art. 24, Feb. 10, 1947, GR. BRIT. T.S. No. 53 (1948); Treaty of Peace with Romania art. 23, Feb. 10, 1947, 61 Stat. 1757, 42 U.N.T.S. 3.

209 See supra note 184.

210 Recovery of Identifiable Property Removed from Allied Countries (June 5, 1947), reprinted in 16 DEP'T STATE BULL. 1143, 1161 (1947).

211 U.S. Initial Post-Surrender Policy for Japan (Sept. 22, 1945), reprinted in 13 DEP'T STATE BuLL. 421, 426 (1945).

212 General of the Army Macarthur, Far Eastern Commission Summary Report

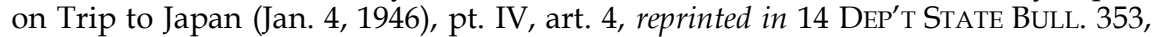
371 (1946).

213 Recovery of American Property Confiscated by Japanese in China (Oct. 16,

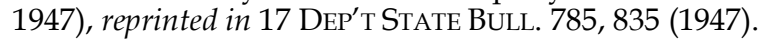

214 The London Declaration, supra note 184.

215 The Final Act of the United Nations Monetary and Financial Conference, supra note 186, at art. 6; see also the Report of Commission III (Other Measures for International Monetary and Financial Cooperation) to the Executive Plenary Session (Jul. 21, 1944), id. at 114. 
States, France, and Britain concluded the agreement on the control of looted works of art on July 8, 1946, in order to make joint efforts to escalate the search for and restoration of plundered cultural treasures located within neutral states. ${ }^{216}$ Switzerland signed the Currie Protocol on April 8, 1945, which obliged the Swiss to pass a law to enforce the restitution of plundered artifacts. ${ }^{217}$ Switzerland thus adopted the law on December 10, 1945, and established a special procedure to sort out claims for restitution of looted properties.218 Sweden likewise enacted the Looted Objects Law in 1945, which placed a stricter responsibility on the government to enforce restitution and obliged the State Treasury to pay the amount due to Swedish citizens who qualified as good-faith purchasers. ${ }^{219}$

These efforts to facilitate restitution were not limited to states in Europe and Asia that had engaged in military actions during World War II. The Resolution of the Mexican Delegation Dealing with the Problems of Looted and Enemy Property delivered on March 2, 1945, represented joint efforts of American states in promoting the restitution of artifacts plundered by Germany and Japan to their countries of origin. ${ }^{220}$

\section{A GENERAL OR EUROPEAN CIL RigHT TO RESTITUTION?}

This Part examines the scope of the application of the CIL Right to Restitution in two sections. First, it inquires whether the CIL right to restitution was a general CIL rule or a mere European custom, because state practices in law-making were more often shown in Europe before the twentieth century. Second, it investigates whether the so-called standard of civilized nations, which was articulated to exclude non-Western nations from participating in international society in the nineteenth century, would prevent the CIL right to restitution from applying to non-Western nations. These discussions will impact whether claims for restitution can be established today for states that suffered the looting of cultural

216 Statement of Policy with Respect to the Control of Looted Articles, Paris,

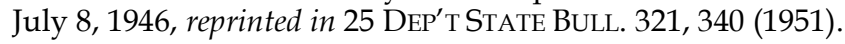

217 KowALSKI, supra note 3, at 63.

218 Id.

219 Id.

220 Oscar Cox, Resolution of Mexican Delegation Dealing with the Problems of Looted and Enemy Property (Mar. 2, 1945), reprinted in 12 DEP'T STATE BuLL. 319, 350-51 (1945). 
property during nineteenth-century warfare to recover these artifacts.

\section{a. The Evolution and Application of the Law of War}

There likely exists some doubt as to whether the CIL right to restitution was a general CIL rule or merely a European custom because European states engaged in law-making practices more frequently before the twentieth century. Admittedly, the acts of refraining from confiscating cultural objects as spoils of war and restitution afterwards were distinctively European practices. However, the essential issue is whether the customary law of nations underlying these practices had or should be deemed to have had a universal application at that time. Since applying the current law-making rules would violate the non-retroactivity principle, it is thus necessary to use the contemporaneous law-making criteria for this inquiry.

As this article investigates, mandatory customary law of nations existed during the seventeenth and eighteenth centuries, which required both usages and adherence to the law of nature. Usages could be merely European practices, but the law of nature was considered to apply to all nations, including non-European nations at that time.221 The universal law of nature was especially applied in the law of war. As Judge Lord Stowell observed, within the law of nations, although the rules of trade did not apply to the regions outside of Europe, the basic rules of war had a universal application to all nations.222 The CIL rules prohibiting plunder and providing restitution as the remedy for violations of the rule, which were established in the law of war at the end of the eighteenth century under natural law, were thus considered general CIL rules that applied to all nations.

During the nineteenth century, the theoretical basis of international law was a mix of the law of nature and state consent, which gives a new examination of the evolution of the CIL rule against plunder as well as the right to restitution. In the

221 See GROTIUS, supra note 88, at 42; cf. DE VATTEL, supra note 64, at $\$ 162$ (arguing that the law of nature also governed treaties between Christian nations and non-Christian nations, because it reflected the nature of humanity beyond the boundaries of religions).

222 TWISS, supra note 176 , at 162. 
circumstances of Napoleon's looting, this rule was not eroded but indeed strengthened, as demonstrated by the means of his looting, the public sentiment, and the reactions from other states to his acts. Although state consent to restitution after Napoleon's defeat was made only by European sovereigns, such consent was a clear reflection of the universal law of nature that prohibited wartime plunder of cultural artifacts. ${ }^{223}$ Castlereagh also argued that Napoleon's looting was "contrary to every principle of justice, and to the usages of modern warfare." 224 "Modern" in this sentence was a plain interpretation of time rather than a limitation on regions.

Codification of the laws and customs of war by a series of international agreements in the second half of the nineteenth century provides another example showing that the CIL rule against plunder was applied to all nations. As the history of war repeatedly demonstrated, military parties participating in warfare often failed to faithfully obey the law of war in the form of CIL. 225 Inspired by Lieber's model, European states began to recognize the necessity of having state consent regarding common understandings of military rules, so that these rules would be better executed in military practices. ${ }^{226}$ This shared opinion led to the convening of the Brussels Conference, the publication of the Oxford Manual, and finally the adoption of the Hague Conventions of 1899 and 1907, which all included the codification of the CIL rule against plunder. As this history reveals, state consent was not adopted to create new rules of warfare, but rather, as a means to strengthen the binding basis of existing rules that were previously established on a natural law basis with universal application. The CIL rule against plunder thus remained universally valid even though the philosophy of international law shifted away from natural law toward positivism.

\footnotetext{
223 See discussion supra Section IV.A.5.

224 Supra note 153, at 204.

225 MARTENS, supra note 126 , at 79-80.

226 Id. at 73-75, 91, 95-96, 98-99.
} 


\section{b. The So-Called Standard of Civilized Nations and Disputes over Spoils of War}

All states are considered civilized today. 227 During the nineteenth century, however, colonial powers framed the standard of civilized nations to exclude non-Western nations from participating in international society. 228 The connection between the standard of civilized nations and disputes over spoils of war thus raises a complexity in the application of international law, i.e., whether the CIL rule against plunder and the right to restitution could be applied to non-Western nations at that time. ${ }^{229}$ In this section, I first explore the evolution of the standard of civilized nations in history and then inquire as to the actual application of the law of war in military practices, taking the two Opium Wars (18401860) as an example. I argue that the standard of civilized nations was adopted in international law as a criterion for Western nations to enjoy international law-making powers, rather than to exclude

\footnotetext{
227 The standard of civilization no longer exerts legal significance in making or applying the rules of international law. HERSCH LAUTERPACHT, RECOGNITION IN INTERNATIONAL LAW 31 n.1 (1947) ("Modern international law knows of no distinction, for the purposes of recognition, between civilized and uncivilized States or between States within and outside the international community of civilized States"); 2 SIENHO YEE, We Are All "Civilized Nations": Arguments for Cleaning Up Article 38 (1)(c) of the Statute of the International Court of Justice, in TOWARDS AN INTERNATIONAL LAW OF CO-PROGRESSIVENESS 21-35 (2014).

228 For more information on how the standard of civilized nations was employed to exclude non-Western nations from participating in international society, see generally Liliana O. Tarazona, The Civilized and the Uncivilized, in THE OXFORD HANDBOOK OF THE HISTORY OF INTERNATIONAL LAW 917, 938 (Bardo Fassbender \& Anne Peters eds., 2012) ("In the 19th century, civilization became the new a priori claim to European expansion based on an accepted way to classify the progress of peoples or States through a range of imagined values."); Brett Bowden, The Colonial Origins of International Law. European Expansion and the Classical Standard of Civilization, 7 J. HIST. INT'L L. 1 (2005); Antony Anghie, Finding the Peripheries: Sovereignty and Colonialism in Nineteenth-Century International Law, 40 HARV. INT'L L.J. 1 (1999) (focusing on the role of positivism in dispossessing European colonies); Georg Schwarzenberger, The Standard of Civilisation in International Law, 8 CURRENT LEGAL PROBS. 212 (1955); Edward Keene, The Standard of 'Civilisation', the Expansion Thesis and the 19th-century International Social Space, 42 MILLENNIUM J. INT'LSTUD. 651 (2014); Alexander Orakhelashvili, The Idea of European International Law, 17 EUR. J. INT'L L. 315 (2006)

229 In his article, Spitra adopts the Third World Approach to International Law to discuss the relations between the idea of civilization in international law and the historical development of the protection of cultural property during warfare. See Sebastian Spitra, Civilisation, Protection, Restitution: A Critical History of International Cultural Heritage Law in the $1^{\text {th }}$ and $20^{\text {th }}$ Century, 22 J. HIST. INT'L L. 329 (2020).
} 
non-Western nations from applying the law of war during the nineteenth century.

\section{i. The Concept of Civilized Nations Under Natural Law}

The term "civilized nations" was not an innovation of the nineteenth century but was written into the language of the law of nations during the seventeenth and eighteenth centuries. ${ }^{230}$ The standard of civilized nations first referred to Christianity during the seventeenth century, but was later developed toward the use of reason due to the impact of the Enlightenment era during the eighteenth century. ${ }^{231}$ As Wolff defined, a civilized nation was "a cultured nation which cultivates intellectual virtues ... . has civilized usages or usages which conform to the standard of reason and politeness." 232 In this respect, Wolff recognized China as a civilized nation because of its great achievements in moral philosophy and statecraft, despite its slower development in physics and mathematics than that of Europe. ${ }^{233}$

Remarkably, classical international law writers did not regard the standard of civilized nations as a legal threshold to exclude nonWestern nations from applying the law of nations. Grotius recognized the different progress of civilization in different peoples but observed a universal application of international law to all nations. ${ }^{234}$ Wolff argued that all nations were equal by nature, regardless of their different rates of progress as civilizations. 235 The equality of all nations was also long recognized as a fundamental

230 See, e.g., 2 GrotiUs, supra note 88, at 208 ("Hence this type of ownership, which by common acceptation of civilized nations has been introduced in favour of infants and those of similar condition"); WOLFF, supra note 58, at 17, 33.

231 See Tarazona, supra note 228, at 918-21.

2322 WOLFF, supra note 58 , at 34 .

233 See id. at 35.

234 Hugo Grotius, The Freedom of the SEAS OR the Right Which BeLONGS TO THE Dutch to TAKe PART IN THE EAST Indian TRAde 5 (Ralph van Deman Magoffin trans., James Brown. Scott ed., 1916). ("For it is a law derived from nature, the common mother of us all, whose bounty falls on all, and whose sway extends over those who rule nations, and which is held most sacred by those who are most scrupulously just.").

235 See 2 WOLFF, supra note 58, at 33-34. 
principle in the law of nations since the Peace of Westphalia of 1648.236

In these writers' views, the standard of civilized nations was not deemed an entrance to deny non-Western nations access to international society, either. According to Wolff, an international society was established among all nations and bound all nations by nature.237 De Vattel likewise viewed that a great society of nations was established by nature among all nations for "the interchange of mutual assistance for their own improvement, and that of their condition." 238

In light of this history, the standard of civilized nations was neither an entrance for non-Western nations joining in international society nor a threshold that excluded these nations from applying the law of war under natural law during the seventeenth and eighteenth centuries.

\section{ii. The Changing Legal Significance of Civilized Nations in the Nineteenth Century}

Only beginning in the nineteenth century, "civilized nations," a term which exclusively referred to those nations that inherited or adopted European or Christian civilization, became a threshold to exclude non-Western nations from membership in international society. 239 Since then, many non-European nations, such as China, were labeled as uncivilized nations. ${ }^{240}$ A controversy arose among

236 Origins of Public International Law, in THE OXFORD INTERNATIONAL ENCYClOPEDIA OF LeGAL History (Stanley N. Katz ed., Oxford Univ. Press 2009), https://www.oxfordreference.com [https://perma.cc/45DF-3TAS] (last visited Apr. 13, 2021).

237 See 2 WoLfF, supra note 58 , at 11.

238 DE VATTEL, supra note 64 , at $\$ 12$ (emphasis added).

239 See, e.g., FEDOR F. MARTENS, VÖLKERRECHT [INTERNATIONAL LAW] 474-75, 480-81 (Berlin, Weidmannache Buchhandlung 1883); TWISS, supra note 176, at 162; William E. HALl, A TREATISE ON INTERNATIONAL LAW $42-43$ (3d ed. 1890); WHEATON $\&$ PHILliPSON, supra note 69 , at 18 . For contemporary comments, see also Tarazona, supra note 228; Bowden, supra note 228, at 1.

240 See WheATMAN \& PHILlipson, supra note 69, at 20. However, Westlake argued that countries such as China, Japan, and Turkey must be recognized as civilized nations, even though their civilizations were different from European models. See The Collected Papers of John Westlake On Public InTERnATIONAL LAW 102-03 (L. Oppenheim ed., 1914). 
jurists at that time as to whether the law of war could apply to uncivilized nations. ${ }^{241}$

However, what was the legal significance of the membership of international community during this period? What was the relationship between the membership of international community and the subjects of international law? Indeed, non-membership of international society did not necessarily deprive non-Western nations of the subjects of international law, because this membership was merely an expression of international law-making power during this period. Prominent jurists, such as John Westlake and Theodore D. Woolsey, argued that law-making power was limited to nations that had inherited or adopted Western civilization. ${ }^{242}$ Their ideas of limiting law-making power to civilized nations were likely affected by Wolff, who admitted that "what has been approved by the more civilized nations is the law of nations." 243 Still, what Wolff meant in his time was that civilized nations had a greater capacity to produce the rules for the law of nations, but all nations were equal in the application of these rules.

Indeed, lack of law-making power did not necessarily exclude non-Western nations from applying the law of nations. For example, during the parliamentary debate of Great Britain in 1840, a debate existed as to whether the law of nations should be applied to relations between Great Britain and China in the Opium War. ${ }^{244}$ As Sir G. Staunton claimed, "Though the Chinese are no parties to the specific usages of international law amongst European nations, they cannot but be bound by that law of nations, which is founded

241 Some jurists argued that international law only applied to civilized nations because it was an ultimate product of their civilization. See WHEATON \& PHILLIPSON, supra note 69, at 14-15; LORIMER, supra note 99, at 102 (“[Civilized communities are not] bound to apply the positive law of nations to savages, or even to barbarians"); HALL, supra note 239. However, a few scholars, such as Johann C. Bluntschli, have argued that international law was not restricted to the European family of nations but applied to all peoples on earth. JOHANN C. BLunTSCHLI, DAS MODERnE VÖLKERRECHT DER CIVILISIRTEN STATEN [THE MODERN INTERNATIONAL LAW OF THE Civilized STATES] para. 7 (1878).

242 The Collected Papers of JOHN Westlake On Public InTERnATIONAL LAW, supra note 240, at 103; THEODORE D. WOOLSEY, INTRODUCTION TO THE STUDY OF INTERNATIONAL LAW §5 (New York, Charles Scribner \& Co. 1871); cf. Tarazona, supra note 228, at 918 ("[O]nly 'civilized' nations could participate in the project of international law.")

2432 WOLFF, supra note 58 , at 17.

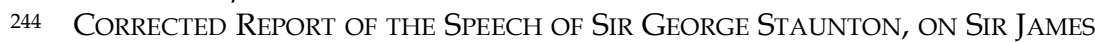
Graham's Motion on the China Trade in the House of COMmONS 11 (London, Edmund Lloyd, Harley Street 1840). 
on the law of nature and of common-sense." 245 Regarding the same issue, John Q. Adams, former U.S. Congressman and President, stated in his public lecture in 1841 that the general and necessary law of nations should definitely apply to the contest between Great Britain and China, which was determined by the law of nature to bind the relations between independent communities. ${ }^{246}$ These statements strongly suggest that the standard of civilized nations was not a threshold in considering whether to apply the law of war to non-Western nations, despite these nations' different civilizations, their exclusion from the process of defining the positive law of nations, and even their lack of knowledge of international law.

State practices of Britain and France during the two Opium Wars also reflected these opinions. During the first Opium War, Queen Victoria issued an order on April 4, 1840, requiring British courts of admiralty to determine all the confiscations of any property in China "the same according to the course of admiralty and the laws of nations." 247 Likewise, during the Second Opium War, Great Britain and France both issued decrees ordering their armies to comply with the rules of maritime law under the Declaration of Paris of 1856. ${ }^{248}$ This Declaration contained a special provision that limited its application only to "the Powers who have signed [the Declaration] or shall accede to it." 249 Great Britain and France were both parties to this Declaration while China was not. However, the rules of maritime law under this Declaration were reflections of customary law of nations at that time. ${ }^{250}$ The practices of Britain and France clearly suggested that they believed that the customary law of nations also applied to the relations between Western powers and China, even though China was neither a member of their international community nor a civilized state according to their standard.

Rather than denying its application to non-Western nations, the standard of civilized nations was indeed employed as a means to

\footnotetext{
245 Id.

246 John Q. Adams, Lecture on the War with China (Dec. 1841), in 11 THE CHINESE REPOSITORY 274, 275-76 (1842).

247 War with China: Order in Council, Presented to Parliament by Her Majesty's Command (Apr. 4, 1840), in 9 THE CHINESE RepOsITORY 241, 244 (1840).

248 TwISS, supra note 176, at xxxi-xxxiii.

249 Id. at xxxi.

250 See id. at xxxii (noting that the Declaration of Paris was to be "less burdensome to Neutrals").
} 
promote the universal application of the law of war. As Wheaton observed, adopting international usages and observing the law of war were essential considerations to determine whether nonWestern nations met the standard of civilized nations. ${ }^{251}$ In other words, non-Western nations had to apply the law of war if these states attempted to join in the international community. In this regard, the standard of civilized nations was a coercive means to promote the universal application of the law of war through recruiting new members of international society, rather than denying the application of these rules to non-Western nations.

Furthermore, as the records show, Western powers sought to apply the laws and customs of war to all nations when they codified these rules during the late nineteenth century. Although fifteen of the states that attended the Brussels Conference were from Europe, the rules of warfare they recognized were intended to impose limits on the actions of all nations, particularly those of major powers. ${ }^{252}$ Consequently, smaller states were interested in taking advantage of this circumstance to protect their rights as well in the event of war. ${ }^{253}$ The two Hague Conferences aimed to define the laws and customs of war that would apply to all nations. ${ }^{254}$ The First Hague Conference (1899) had twenty-six countries attending. ${ }^{255}$ It included all major European powers, as well as the United States and Mexico attending from North America, and China, Japan, Persia, Siam, and Turkey attending from the Near and Far East. ${ }^{256}$ The Second Hague Conference (1907) had forty-four countries attending. ${ }^{257}$ It included all the participants of the First Hague Conference and seventeen additional states from Central and South America. ${ }^{258}$ The two Hague conferences showed that nations with different civilizations could meet and consent to the rules that apply to all nations. These efforts clearly show that Western powers positively promoted the

\footnotetext{
251 WHEATON \& PHLLIPSON, supra note 69, at 18-21.

252 MARTENS, supra note 126, at 105.

253 Id.

254 See The Hague Conventions and Declarations of 1899 and 1907, supra note 128 , at $\mathrm{v}$.

255 Hague Conventions $(1899,1907)$, supra note 26, at 1; John Whiteclay Chambers II, Hague Peace Conferences, OXFord Companion to AM. MiL. Hist. (Mar. 3, 2021), https://www.encyclopedia.com/social-sciences-and-law/politicalscience-and-government/international-organizations/hague-conferences [https://perma.cc/SZM2-VE5N].

256 Hague Conventions (1899, 1907), supra note 26, at 1.

257 Id. at 3.

258 Id.
} 
universal application of the law of war instead of limiting its application among themselves. Therefore, the standard of civilized nations was adopted not as a legal threshold to prevent the law of war from applying to non-Western nations, but rather as a criterion to limit law-making powers to Western nations.

The law of war, admittedly, was not evenly applied to all nations during the nineteenth century. Inconsistent state practices existed in obeying the law of war, as Western powers plundered countless cultural artifacts from non-Western nations during many colonial wars, which give rise to the claims for restitution today. Indeed, the law of war is criticized as always applied to Western states but never evenly applied to non-Western states even nowadays. ${ }^{259}$ However, such uneven application of the law of war reflects gaps between what is the law and to what degree the law is followed and enforced. Substantial non-conformity or non-enforcement of the CIL rule against plunder may undermine the effectiveness of the rule, but may not deny the existence of the rule. In this respect, the confiscations of cultural artifacts by Western powers that were contrary to the CIL rule against plunder, such as the looting of China's Old Summer Palace, should be considered violations of the rule. Restitution of these looted artifacts to their countries of origin thus serves as the most efficient means to strengthen the law conformity and enforcement.

\section{The PASSAGE OF TIME AND THE CIL Right TO RESTITUTION}

There exists skepticism as to whether the CIL right to restitution would be extinguished due to the passage of time. ${ }^{260}$ Invoking the statutes of limitations on the restitution also raises this question. ${ }^{261}$ However, statutes of limitations are indeed irrelevant because statues of this kind only apply within the scope of domestic law

259 See JAMES GATHII, WAR, COMMERCE AND INTERNATIONAL LAW chs. 2-3 (2011).

260 See Merryman, supra note 18, at 1901; Ognibene, supra note 4, at 625-28.

261 See Merryman, supra note 18, at 1901 (discussing how English court's application of statutes of limitations reduce the chance of the Greeks recovering stolen properties); Paige S. Goodwin, Comment, Mapping the Limits of Repatriable Cultural Heritage: A Case Study of Stolen Flemish Art in French Museums, 157 Univ. Pa. L. Rev. 673, 695-96 (2008) (identifying statutes of limitations as possibly hindering recovery of stolen properties). 
rather than public international law. ${ }^{262}$ As for the passage of time, the evolution of the CIL against plunder and in favor of restitution suggest that claims for restitution of cultural artifacts will not be inhibited by the duration of over one and half centuries that have passed since the removal of these artifacts.

This customary norm was first reflected in the practices of restitution that followed Napoleon's defeat. Napoleon plundered cultural artifacts for nearly twenty years. The passage of two decades did not bar restitution claims and actions of victim states. This principle became more obvious in the peace treaties arising from World War I, which included clauses to return cultural artifacts plundered during the previous wars of the eighteenth century. Such restitution clauses were not an occasional provision but became a feature in many of the peace treaties following World War I. This principle was also shown in the peace treaties arising from World War II. These treaties included clauses providing for restitution of looted cultural treasures not only removed during World War II but also those plundered during the Napoleonic Wars nearly one century prior. For instance, the peace treaty with Hungary of 1947 provided for the restitution of cultural treasures confiscated as a consequence of Hungarian rule over certain territories prior to 1919.263 The Treaty of Peace with Italy also stipulated that "Italy shall restore to Yugoslavia all objects of artistic, historical, scientific, educational or religious character ... as well as administrative archives" which were removed as the result of the Italian occupation between November 4, 1918, and March 2, 1924. ${ }^{264}$

Furthermore, state practices have frequently reaffirmed this principle in recent years. For instance, in 2007, the Chilean government returned almost 4000 books that had been looted by Chilean soldiers during its war with Peru (1879-1883) to the National Library of Peru. ${ }^{265}$ As Chilean Senator Alejandro Navarro declared, the books were required to be returned to their legitimate owners

\footnotetext{
262 See Ashraf Ray Ibrahim, The Doctrine of Laches in International Law, 83 VA. L. REV. 647, 648 (1997).

263 The Treaty of Peace with Hungary, supra note 208, at art. 11.

264 The Treaty of Peace with Italy, supra note 208, at art. 12.

265 Dan Collyns, Chile returns looted Peru books, BBC News (Nov. 7, 2007, 10:56 GMT), [https://perma.cc/6AA4-UZZP].
} 
because they were products of looting. 266 Likewise, in 2014, Argentina's then President Cristina Fernandez de Kirchner returned to Paraguay some furniture that had been confiscated by Argentinean armies during the War of the Triple Alliance (18641870).267 As Argentina's governor of Entre Ríos explained during his visit to Paraguay with President Kirchner, "We are going to return objects that were seized by the Miter government . . . as trophies of war," and "we undertook the task and the duty to return them to the Paraguayan government . . .."268 The two cases clearly reflect the opinio juris that both Chile and Argentina believe that they are under international obligations to return these artifacts to the territories where they were removed as spoils of war, and their admission that such an obligation will not be relieved due to the passage of over one century.

In December 2018, U.S. Defense officials and the ambassador returned three church bells to Philippine authorities. ${ }^{269}$ American soldiers had carried these bells away from the Philippines as war trophies in 1899-1902.270 The United States also returned the San Pedro bell, which was similarly looted, to the Philippines in 2016.271 According to retired U.S. Navy Capital Dennis Wright, the United States has returned many bells confiscated as war trophies as a consequence of different armed conflicts to Japan and Russia. ${ }^{272}$

In 2011, France returned to South Korea the unique collections of Korean royal archives produced during the Joseon Dynasty, which were seized by French armies during their invasion of Korea in the nineteenth century. ${ }^{273}$ France's then President François

266 _Chile/Perú: diplomacia de los libros, BBC News (Mar. 30, 2007, 14:40 GMT), http://news.bbc.co.uk/hi/spanish/misc/newsid_6510000/6510819.stm [https:// perma.cc/533Q-KCSY].

267 Oficial: Cristina y Urribarri viajaron a Paraguay a devolver muebles [Official: Cristina and Urribarri Traveled to Paraguay to Return Furniture], PERFIL (Aug. 12, 2014, 23:56), http://www.perfil.com/noticias/politica/Oficial-Cristina-y-Urribarriviajaron-a-Paraguay-a-devolver-muebles-20140812-0054.phtml [https://perma.cc/VWN6-KSAT].

$268 I d$. (quoting as translated by the author of this article)

269 McCarthy, supra note 23.

270 See Id.

$271 \quad I d$.

$272 I d$.

273 See Oegyujanggak Uigwe Finally Returns, NAT'L MuSEUM KOR. (Apr. 8, 2011), https://www.museum.go.kr/site/eng/archive/united/9162 [https://perma.cc/YQW8-G9FE]. 
Mitterrand first agreed to return these collections in 1993. 274 However, this decision could not be enforced because French law prohibits state-owned cultural artifacts from being transferred abroad. ${ }^{275}$ After seventeen years' silence, former French President Nicolas Sarkozy confirmed on November 12, 2010 that France would return these collections. ${ }^{276}$ The rationale behind his agreement to return the collections, however, is vague. As Sarkozy explained, "I know that for Koreans, these documents are very much a part of Korean heritage." 277 His statement sought to show sympathy and avoided the important question of whether this return was made due to an international obligation, moral duty, or merely as a friendly gesture for diplomatic purposes. However, the French government's method of proceeding with the return seemed to be based upon more than a sympathy. To avoid the potential violation of the French law that prohibits such transfer, the French government agreed that the return of Korean Royal archives took the form of a five-year renewable loan, which would be automatically renewed every five years. ${ }^{278}$ This agreement thus secured that the collections would permanently stay in Korea. The National Museum of Korea and the National Library of France in Paris then concluded an agreement to facilitate the return on March 16,2011 , and the 297 volumes of the royal archives were finally returned all at once. ${ }^{279}$

Although President Sarkozy did not admit that France bore an international obligation to return these collections, such obligation cannot be denied under CIL that requires restitution to correct the international wrongdoings when state armies or agencies confiscated cultural artifacts as spoils of war. This CIL obligation to restitution also explains why the French government was willing to exploit a loophole in its law to provide the permanent loan of the Korean royal archives, so that the restitution would not violate the domestic law that would otherwise prohibit such transfer.

\footnotetext{
274 See Korea, France Clinch Deal on Return of Royal Archive, CHOsun MediA (Nov. 13, 2010, 08:58), http://english.chosun.com/site/data/html_dir/2010/11/13/2010111300290.html [https://perma.cc/VFQ3-EMLX]. 
More recently, French lawmakers reached a unanimous vote in October 2020 to return twenty-six prized artifacts preserved currently at the Quai Branly Museum in Paris to Benin.280 These artifacts once were plundered during the 1892 pillaging of the palace of Abomey in Dahomey, and Benin is expected to receive these artifacts within a year since this vote. ${ }^{281}$

The customary norm regarding duration in terms of restitution of cultural artifacts removed during international warfare strongly suggests that the passage of over one and a half centuries does not bar the right to restitution. This customary norm is significant today, because in many cases, the looting occurred well over a century ago.282 Establishing this customary norm thus provides a firm legal ground for states claiming restitution today.

\section{LIMITATIONS TO THE RIGHT TO RESTITUTION}

As previously analyzed, countries of origin have the right to the restitution of cultural artifacts removed as spoils of war in nineteenth-century warfare. However, does this right mean that every piece of plundered artifacts must be returned? This Part considers the limitations to enforce restitution, which require that the objects for restitution still exist and are identifiable, with a practical consideration of necessity that should be determined by claiming states.

280 Benin feels 'heard' after France votes to return artefacts, MSN (Oct. 8, 2020), [https://perma.cc/7GJL-FKB4].

$281 \mathrm{Id}$.

282 See supra text accompanying notes, 5-13; see, e.g., Constanze Letsch \& Kate Connolly, Turkey wages "cultural war" in pursuit of its archaeological treasures, THE $\begin{array}{lllll}\text { GUARDIAN } & \text { (Jan. 21, 2013, } & \text { EST), }\end{array}$ http://www.theguardian.com/world/2013/jan/21/turkey-cultural-wararchaeological-treasure [https://perma.cc/T2QS-VHMU]; Charlotte Edwardes \& Catherine Milner, Egypt demands return of the Rosetta Stone, TELEGRAPH (July 20, 2003, 00:01AM),

http://www.telegraph.co.uk/news/worldnews/africaandindianocean/egypt/14 36606/Egypt-demands-return-of-the-Rosetta-Stone.html [https://perma.cc/V95JHLFN]; Return of Displaced Cultural Property from Abroad, JIKJI, http://korea.prkorea.com/wordpress/?p=309 [https://perma.cc/W74H-TBXZ]. 


\section{a. The Requirement that the Objects Still Exist and Are Identifiable}

The requirement that the objects still exist is the prerequisite to enforcing restitution. According to Article 35(a) of Articles on State Responsibility, a situation in which the objects for restitution are "materially impossible" to return can preclude the obligation to restitution. ${ }^{283}$ The rationale is clear. One cannot return property that physically no longer exists. This situation arose when France was asked to return plundered artifacts after Napoleon's defeat; however, many cultural properties were already ruined by the time that the allied powers claimed their right of restitution. ${ }^{284}$

The principle of identification marks another limitation to restitution, requiring that cultural artifacts for restitution have to be identified as those that were in fact plundered from the territory of removal; otherwise, it is impossible to restore the former possession. 285 In the case of Napoleon's restitution, it was impractical for victim states to recover all their lost cultural artifacts because many of these artifacts could not be found. First, there was no written record stating what had been plundered from other European nations or what had been stored in French museums. ${ }^{286}$ Therefore, states took mostly what was easily demonstrably theirs. ${ }^{287}$ Furthermore, many of Napoleon's plundered artifacts were first stored in Paris museums, but then were secretly transferred to provincial churches and museums to avoid being discovered during the peace negotiations. ${ }^{288}$ Without any comprehensive records, such concealment made it very difficult for claiming states to track down lost treasures.

\section{b. Necessity of Restitution}

It is sometimes not necessary for countries of origin to recover all pieces of plundered artifacts for practical considerations, such as

\footnotetext{
283 Rep. on the Work of its Fifty-Third Session, supra note 42, art. 35(a),

284 See Sandholtz, supra note 156, at 152.

285 See KOWALSKI, supra note 3, at 46-47, 50.

286 TREUE, supra note 3, at 193.

287 Id.

288 See Sandholtz, supra note 156, at 152.
} 
the cost of transportation or convenience. ${ }^{289}$ The goal is usually to regain lost cultural property that is truly significant to the cultural heritage of a nation. For instance, in the looting of China's Old Summer Palace case, it has been estimated that over one and a half million artifacts were plundered by the joint British and French armies in 1860.290 Would the Chinese government expect a full restitution, even if these pieces were all discovered one day? The pieces most important to recover would be the unique and irreplaceable artifacts, such as the series of copper zodiac animal heads removed from a main fountain, which constituted a special feature of the Old Summer Palace architecture. 291 Likewise, countless cultural properties were looted by British armies from India during the nineteenth century, and it would be difficult, if not impossible, to recover them all. Among these spoils of war, the Kohinoor diamond is of special importance to India not merely as a piece of jewelry, but also because of its associations with Indian kings over hundreds of years. ${ }^{292}$ The unique symbolic meaning that the Kohinoor diamond represents in the history of ancient Indian civilization makes this diamond irreplaceable to Indian cultural heritage.

Restitution in this context thus does not merely mean a complete restoration of the situation to the status quo ante in order to seek justice, but it combines with a consideration of necessity. In this sense, it is reasonable to conclude that countries of origin have the right to receive full restitution limited by necessity as a practical consideration. Moreover, which items are ultimately included in the inventories of restitution should be determined by countries of origin, since they have the best judgment of the value of various artifacts to their cultural legacy.

\footnotetext{
289 See TREUE, supra note 3, at 198 (noting that Austrians exchanged a large painting for a smaller one, since the latter was easier to dispatch, and the Florentines abandoned twenty-nine paintings to the Louvre due to the probable cost of transport).

290 China's State Bureau of Cultural Property Condemned the British Auction House to Sell the China's Old Summer Palace Plunders, supra note 11.

291 The series of copper zodiac animal heads removed from China's Old Summer Palace were frequently auctioned by Sotheby's and Christie's in recent decades. See Bowlby, supra note 13.

292 See Saby Ghoshray, Repatriation of the Kohinoor Diamond: Expanding the Legal Paradigm for Cultural Heritage, 31 FORDHAM INT'L L.J. 741, 746-48 (2008).
} 


\section{CONCLUSION}

Throughout the nineteenth century until the present, the CIL law of war has prohibited the looting of cultural property and required restitution as the primary form of reparations for such violations. The CIL rule against plunder was established in the laws and customs of war under natural law jurisprudence at the end of the eighteenth century. This rule remained valid throughout the nineteenth century, even though the philosophy of international law changed from natural law toward positivism. It was further developed during the twentieth century and finally led to the 1954 Hague Convention as well as its protocols.

The CIL right to restitution is based on the first-tier international obligation that prohibits the plunder of cultural property during wartime. During the seventeenth and eighteenth centuries, restitution was deemed to be the legal remedy when the capture of property was made contrary to the law of war. Acts of restitution that occurred after Napoleon's time and the two World Wars consistently reflect that restitution serves as the primary remedy for violations of the law of war against plunder.

The evolution of the CIL rules that prohibit the looting of cultural property and require restitution shows that these rules were not merely European customs, but rather general CILs that should apply to all nations. The so-called standard of civilized nations was merely a means to limit law-making powers to Western nations, rather than to deny the application of the law of war to other nonEuropean nations during the nineteenth century. Moreover, even the passage of over one and a half centuries since the removal of cultural artifacts does not inhibit claims for restitution. The CIL right to restitution require that plundered artifacts still exist and are identifiable, otherwise this right could not be enforced. Claiming states have the right to determine the necessity of restitution as a practical consideration.

These arguments strongly rebut the presumptions that there were no rules in the law of war during the nineteenth century that regulated military practices in respect of cultural artifacts, and there is no basis in international law today for claiming restitution. This article thus provides an original interpretation of CIL-making in the law of war that prohibits looting cultural property, paving the legal grounds for claiming historically looted cultural property today. 
Applying these conclusions to current disputes would ultimately transform the current debates about restitution and retention. 